\title{
The Molecular Genetics of Myeloproliferative Neoplasms
}

\author{
Anna E. Marneth ${ }^{1}$ and Ann Mullally ${ }^{1,2,3}$ \\ ${ }^{1}$ Division of Hematology, Department of Medicine, Brigham and Women's Hospital, Harvard Medical School, \\ Boston, Massachusetts 02115, USA \\ ${ }^{2}$ Broad Institute, Cambridge, Massachusetts 02142, USA \\ ${ }^{3}$ Dana-Farber Cancer Institute, Harvard Medical School, Boston, Massachusetts 02115, USA \\ Correspondence: amullally@partners.org
}

Activated JAK-STAT signaling is central to the pathogenesis of $B C R$ - $A B L$-negative myeloproliferative neoplasms (MPNs) and occurs as a result of MPN phenotypic driver mutations in $J A K 2, C A L R$, or MPL. The spectrum of concomitant somatic mutations in other genes has now largely been defined in MPNs. With the integration of targeted next-generation sequencing (NGS) panels into clinical practice, the clinical significance of concomitant mutations in MPNs has become clearer. In this review, we describe the consequences of concomitant mutations in the most frequently mutated classes of genes in MPNs: (1) DNA methylation pathways, (2) chromatin modification, (3) RNA splicing, (4) signaling pathways, (5) transcription factors, and (6) DNA damage response/stress signaling. The increased use of molecular genetics for early risk stratification of patients brings the possibility of earlier intervention to prevent disease progression in MPNs. However, additional studies are required to decipher underlying molecular mechanisms and effectively target them.

\begin{abstract}
$M_{a}^{v}$ yeloproliferative neoplasms (MPNs) are a collection of hematopoietic disorders characterized by excessive proliferation of hematopoietic cells of the myeloid lineage. MPNs are classified based on the presence (chronic myeloid leukemia [CML]) or absence of the $B C R-A B L$ translocation. In the majority of cases, $B C R-A B L$-negative MPN is caused by somatic mutations that arise in the hematopoietic stem cell (HSC) compartment and activate the JAKSTAT signaling pathway (Mead and Mullally 2017). $B C R-A B L$-negative MPN is the focus of this review and will be referred to as MPN for the
\end{abstract}

remainder of the review. The JAK2-STAT signaling cascade is activated on binding of ligands to type I cytokine receptors including MPL (thrombopoietin [TPO] receptor), the erythropoietin (EPO) receptor, and the granulocyte colony-stimulating factor receptor (G-CSF) receptor. Mutations that activate the JAK-STAT signaling pathway render hematopoietic stem and progenitor cells (HSPCs) hypersensitive to cytokines. Different subtypes of MPN are classified descriptively based on the predominant lineages involved: elevated platelet count in essential thrombocythemia (ET); elevated red

Editors: Michael G. Kharas, Ross L. Levine, and Ari M. Melnick

Additional Perspectives on Leukemia and Lymphoma: Molecular and Therapeutic Insights available at

www.perspectivesinmedicine.org

Copyright (C) 2020 Cold Spring Harbor Laboratory Press; all rights reserved; doi: 10.1101/cshperspect.a034876

Cite this article as Cold Spring Harb Perspect Med 2020;10:a034876 
A.E. Marneth and A. Mullally

blood cell count in polycythemia vera (PV); megakaryocytic hyperplasia and bone marrow fibrosis in myelofibrosis (MF). ET and PV can evolve into MF (termed secondary MF) or patients may present with de novo MF (termed primary MF or PMF). All subtypes of MPN can transform into secondary acute myeloid leukemia (sAML), which is typically refractory to chemotherapy and generally carries a poor prognosis.

\section{MUTATIONS IN THE JAK-STAT SIGNALING PATHWAY}

Mutations that activate the JAK-STAT signaling pathway (Fig. 1) are disease-initiating in MPNs and consequently are termed MPN phenotypic driver mutations. The most frequent MPN phenotypic driver mutation occurs in $J A K 2$, a gene encoding a nonreceptor tyrosine kinase. The mutation results in a valine to phenylalanine substitution at position 617 (V617F) in the JH2 domain of the protein, negating the otherwise repressive function of this domain on kinase activity (Chen and Mullally 2014). JAK2 acts as an intermediate signaling molecule for several growth factor receptors including myeloproliferative leukemia (MPL), the EPO receptor, and $\mathrm{G}-\mathrm{CSF}$ receptor. As a consequence, patients with $J A K 2$ mutations may have thrombocytosis (ET, $50 \%-60 \%$ of patients have a $J A K 2^{\mathrm{V} 617 \mathrm{~F}}$ mutation; see Table 1), erythrocytosis (PV, 95\% of patients have a $J A K 2^{\mathrm{V} 617 \mathrm{~F}}$ mutation), and leukocytosis (observed in PV). JAK2 exon 12 mutations, occurring in $2 \%-3 \%$ of $\mathrm{PV}$ patients, also result in constitutive activation of JAK2 signaling and typically present with isolated erythrocytosis (Scott et al. 2007). The second most frequent MPN phenotypic driver mutation is found in the endoplasmic reticulum chaperone,

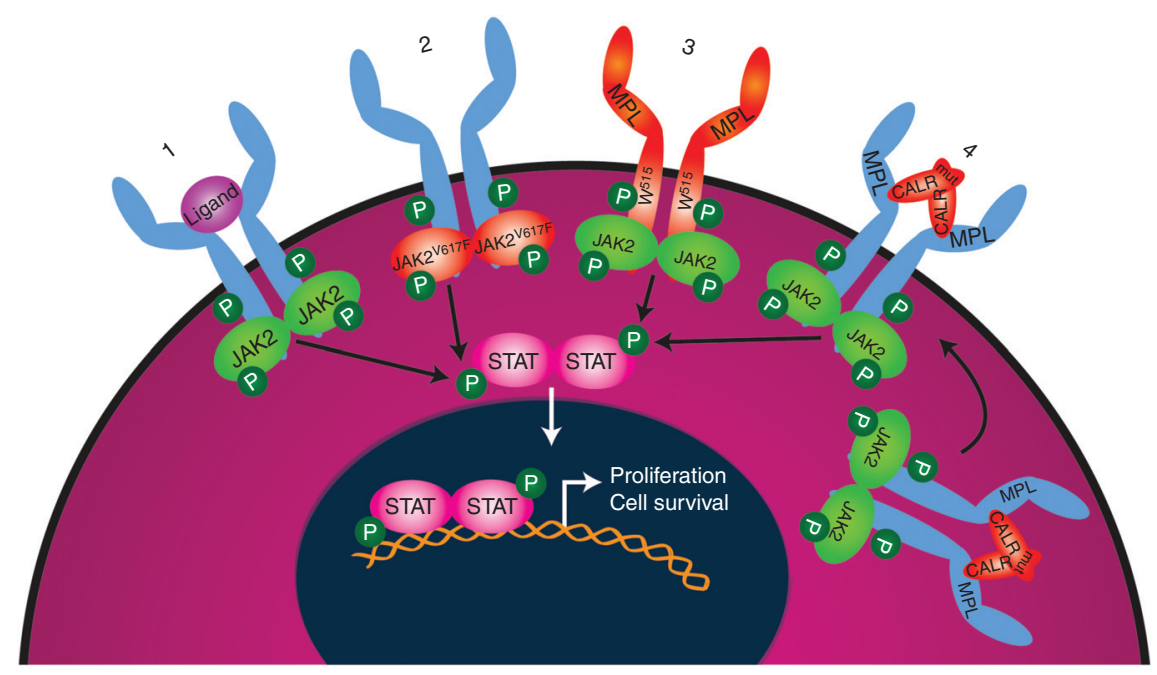

Figure 1. Mutations activating the JAK-STAT signaling pathway are sufficient to cause myeloproliferative neoplasm. In the normal situation (1), the JAK-STAT signaling pathway is activated on binding of a ligand to type I cytokine receptors including MPL (thrombopoietin [TPO] receptor), the erythropoietin (EPO) receptor, and granulocyte colony-stimulating factor (G-CSF) receptor. Activation of the JAK-STAT signaling pathway causes cell proliferation and survival of the relevant myeloid lineage cells. When JAK2 is constitutively active owing to mutations such as V617F (2), downstream signaling from type I cytokine receptors is increased, leading to clonal expansion of hematopoietic stem cells (HSCs), increased erythropoiesis (EPOR), thrombopoiesis (MPL), and granulopoiesis (G-CSFR). Situation (3) shows that MPL mutations at position W515 activate JAK-STAT signaling. In situation (4), mutant CALR develops a pathogenic binding interaction with MPL (but not with EPO or G-CSF receptor) that activates JAK-STAT signaling. In situations (3) and (4), because only the MPL receptor is involved, JAK-STAT pathway activation is restricted to MPL-expressing hematopoietic stem cell (HSC) and megakaryocyte lineage cells resulting in thrombocytosis. Mutated proteins are depicted in orange. P, Phosphorylation. 

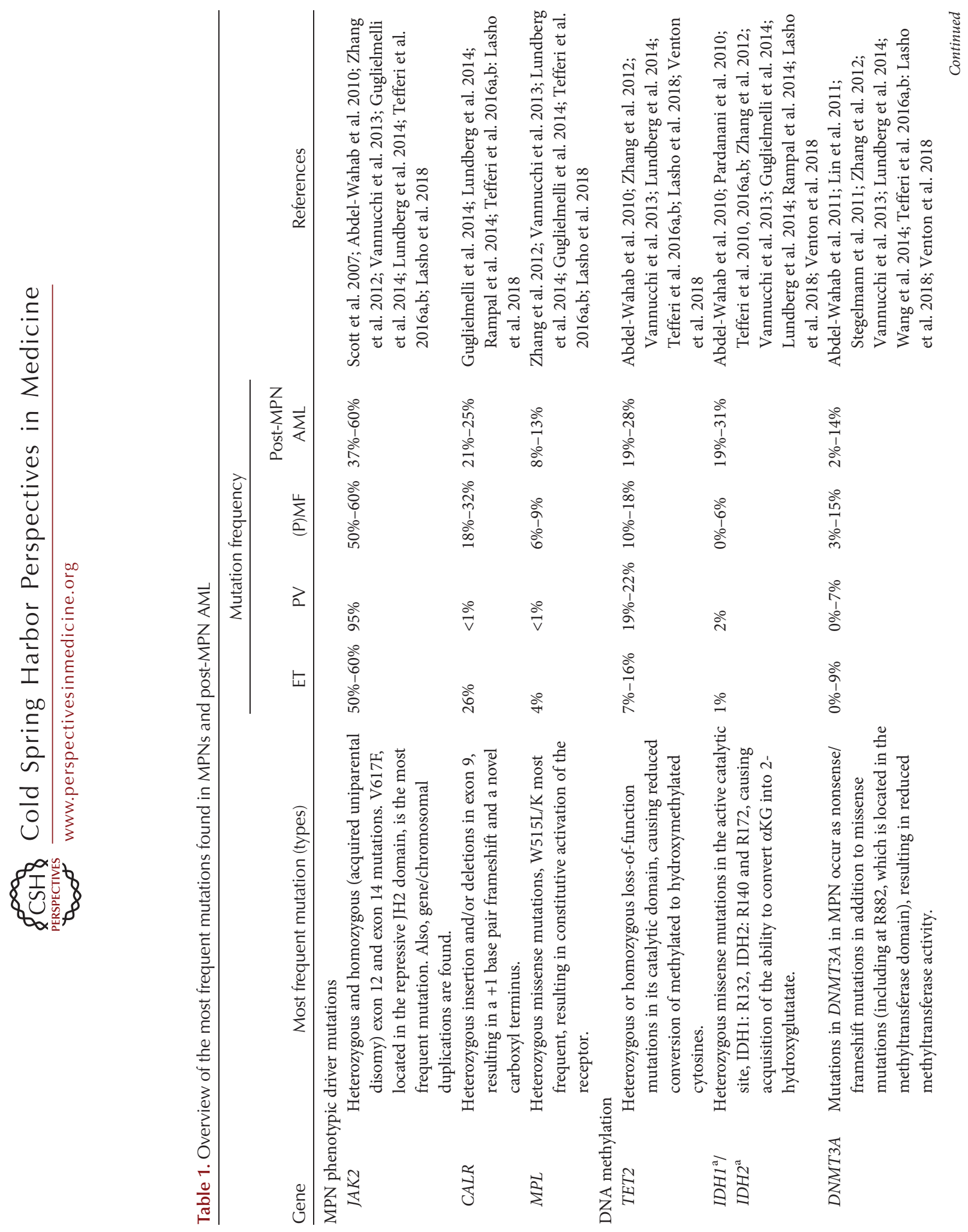
A.E. Marneth and A. Mullally
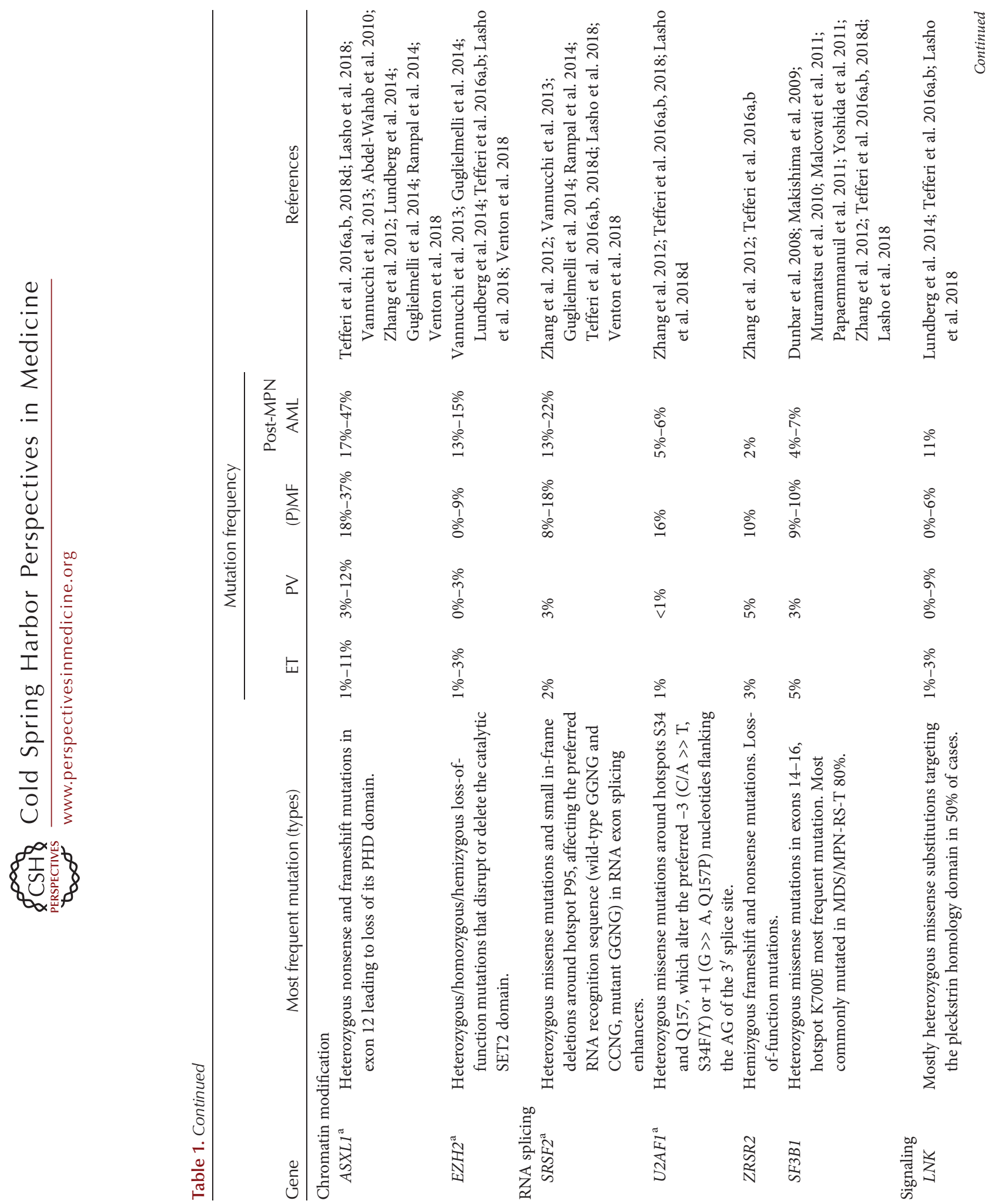
Molecular Genetics of MPNs
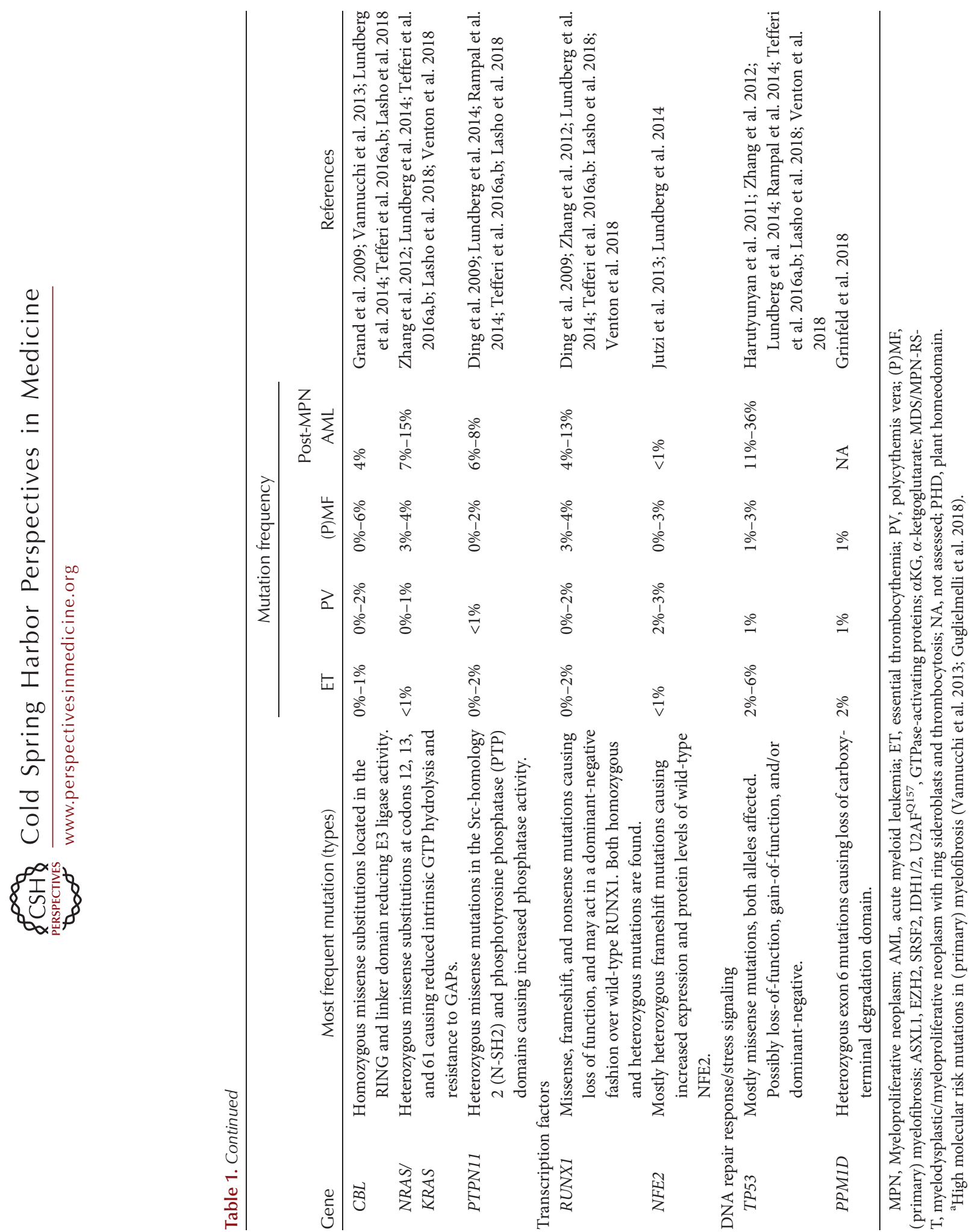
CALR. CALR mutations occur as heterozygous insertion and/or deletions in exon 9, resulting in a +1 base pair frameshift (Klampfl et al. 2013; Nangalia et al. 2013). This frameshift changes the reading frame and results in the generation of a novel mutant-specific carboxyl terminus. CALR induces MPN by binding to and activating MPL signaling in a TPO-independent manner (Elf et al. 2016). Consistent with the observation that MPL is mostly expressed in HSCs and the megakaryocytic lineage, mutations in CALR occur in ET (26\%) and MF but not typically in PV. The third most frequent MPN phenotypic driver mutation occurs in $M P L$, with the majority of mutations located at tryptophan 515 (W515L/K) (Pikman et al. 2006). MPL mutations primarily affect the megakaryocytic lineage and are present in ET (4\%) and MF, but not in PV. Mutational frequencies in PMF are 50\%-60\% for JAK2 mutations, $18 \%-32 \%$ for $C A L R$, and $6 \%-9 \%$ for $M P L$ (Table 1). Additionally, $\sim 10 \%$ of ET and PMF patients are "triple negative"- they do not harbor JAK2, CALR, nor MPL mutations (Angona et al. 2016; Milosevic Feenstra et al. 2016).

It is important to note that mutations in $J A K 2, C A L R$, or MPL are sufficient "alone" to engender MPNs in people and in mice (Pikman et al. 2006; Mullally et al. 2013; Li et al. 2018). In $45 \%-50 \%$ of MPN cases, an MPN phenotypic driver mutation is the sole mutation identified based on our current knowledge of genes known to be somatically mutated in myeloid malignances (Lundberg et al. 2014; Grinfeld et al. 2018), and in a recent study all MPN patients of $<39$ years old had $J A K 2$, CALR, or MPL as the sole mutation identified (Grinfeld et al. 2018). Furthermore, JAK2 ${ }^{\mathrm{V} 617 \mathrm{~F}}$ is a common mutational driver of clonal hematopoiesis of indeterminate potential (CHIP), an entity in which clonally restricted somatic mutations in genes associated with hematological malignancies are found in normal individuals (Gibson and Steensma 2018). In virtually all cases of JAK2 $2^{\mathrm{V} 617 \mathrm{~F}}$ CHIP, the JAK2 mutation occurs as an isolated event indicating that $\mathrm{JAK} 2^{\mathrm{V} 617 \mathrm{~F}}$ alone is sufficient to cause clonal hematopoiesis (Jaiswal et al. 2014). The prevalence of JAK2 ${ }^{\mathrm{V} 617 \mathrm{~F}} \mathrm{MPN}$ is significantly lower than that of JAK2 $2^{\mathrm{V} 617 \mathrm{~F}}$
CHIP (Hinds et al. 2016), suggesting there are factors that constrain and promote the transition from JAK2 ${ }^{\mathrm{V} 617 \mathrm{~F}}$ clonal hematopoiesis to MPN. Recent studies indicate that JAK2 ${ }^{\mathrm{V} 617 \mathrm{~F}} \mathrm{CHIP}$ is itself a clinically relevant entity, being associated with an increased risk of both atherosclerotic heart disease (Jaiswal et al. 2017) and venous thrombosis (Wolach et al. 2018). These data suggest that JAK2 mutations can cause a continuum of clinically relevant disease entities, from premalignant clonal expansion to all three classical MPNs.

\section{OTHER SOMATIC GENE MUTATIONS}

Besides the three JAK-STAT activating MPN phenotypic driver mutations, $>50 \%$ of MPN patients harbor additional somatic mutations (Table 1) (Grinfeld et al. 2018). Figure 2 shows an illustrative example of the acquisition of somatic mutations in different hematopoietic states (e.g., polyclonal hematopoiesis, CHIP, MPN, and post-MPN AML). The most common classes of concomitant somatic mutations found in MPN patients are (1) DNA methylation (TET2, IDH1, IDH2, DNMT3A), (2) chromatin modification (ASXL1, EZH2), (3) RNA splicing (SRSF2, U2AF1, SF3B1, and ZRSR2), (4) signaling pathways (LNK/SH2B3, CBL, NRAS, KRAS, PTPN1), (5) transcription factors (RUNX1 and NFE2), and (6) DNA damage response/stress signaling (TP53, PPM1D) (Fig. 3). Below, we describe in which MPN subtypes these mutations are found and how specific mutations affect gene function and contribute to MPNs.

\section{DNA METHYLATION}

\section{TET2}

\section{Consequences of Mutations on Gene Function}

During DNA replication, methylated cytosines are either replaced passively by unmethylated cytosines or actively after a process of chemical modifications initiated by ten eleven translocation (TET) proteins. The TET2 enzyme catalyzes oxidation of 5-methylcytosine to 5-hy- 


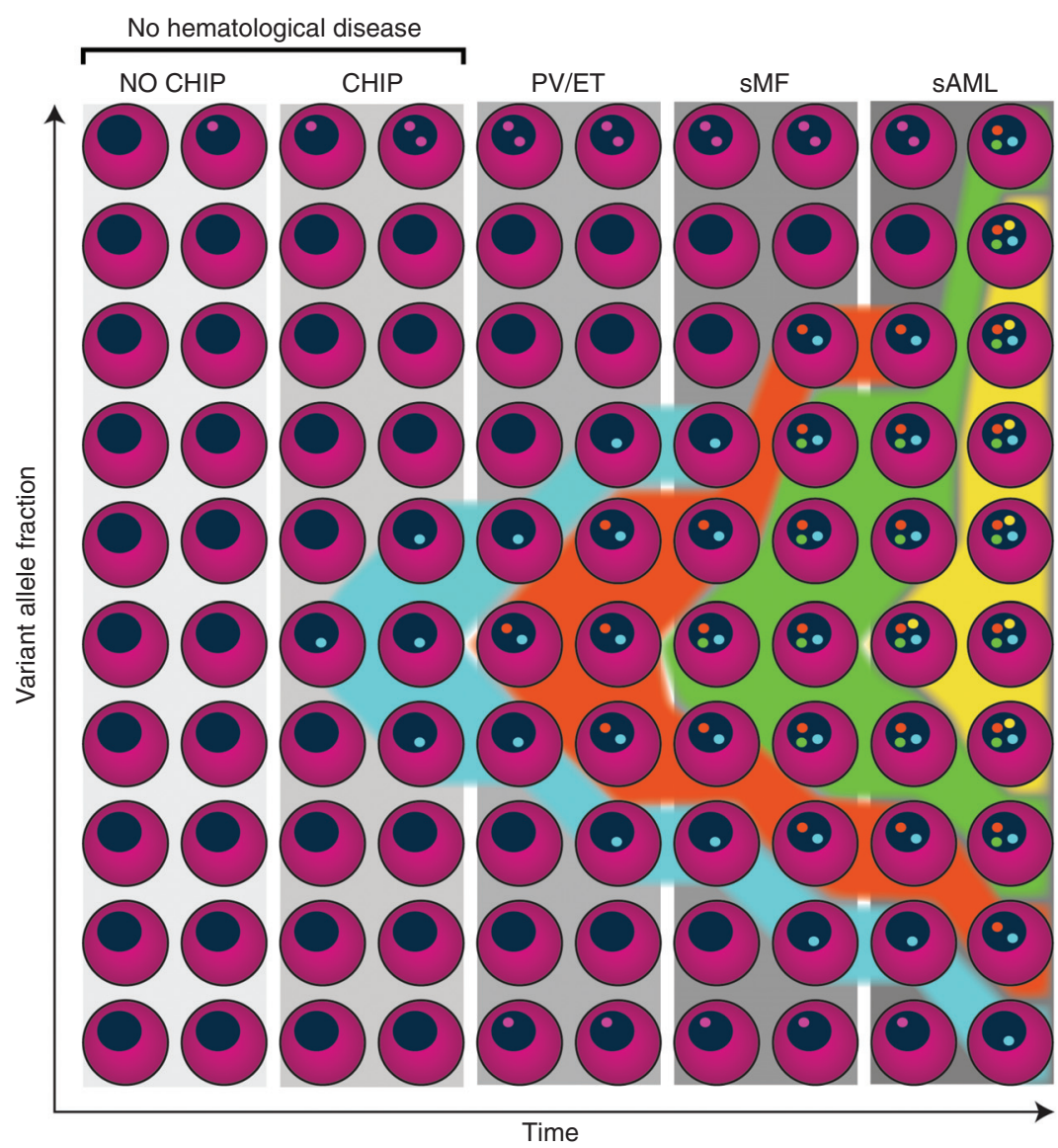

Figure 2. Illustrative example of an individual case with clonal hematopoiesis and myeloproliferative neoplasm (MPN) disease progression. Individuals without hematological diseases may have somatic mutations in genes that do not impact hematopoiesis (i.e., passenger mutations, indicated with pink dots). At some point, the individual case represented in this figure acquires a mutation (e.g., in DNMT3A) that causes clonal expansion of the hematopoietic stem cell (HSC) without necessarily causing an overt hematological disease (i.e., clonal hematopoiesis of indeterminate potential [CHIP]), indicated with blue dots and expansion of the blue clone from $10 \%$ to $30 \%$. Subsequently, this individual acquires one of the MPN phenotypic "driver" mutations (e.g., $\mathrm{JAK} 2^{\mathrm{V} 617 \mathrm{~F}}$, indicated with orange dots), that results in the development of an MPN (e.g., polycythemia vera $[\mathrm{PV}]$ or essential thrombocythemia [ET]). Chronic phase MPN (i.e., PV or ET) may then progress to secondary myelofibrosis (sMF) on acquisition of additional mutations (e.g., a mutation in EZH2 [indicated with green dots]). This clone expands over time and, finally, overt secondary acute myeloid leukemia (sAML) may arise on acquisition of a TP53 mutation (yellow dots).

droxymethylcytosine (5-hmc). TET proteins depend on $\alpha$-ketoglutarate $(\alpha \mathrm{KG}), \mathrm{Fe}^{2+}$, and ascorbate for their dioxygenase activity (Tahiliani et al. 2009; Minor et al. 2013). Mutations in TET2 are loss-of-function causing impaired catalytic function, resulting in reduced levels of 5-hmc and resultant DNA hypermethylation (Fig. 3).

\section{Clinical Data}

All types of mutations and deletions are found throughout the TET2 gene, with the majority of somatic missense mutations found in its catalytic domain. TET2 mutations occur in 7\%$22 \%$ of MPNs and $19 \%-28 \%$ of post-MPN AML patients (Table 1). Although some studies 
A.E. Marneth and A. Mullally

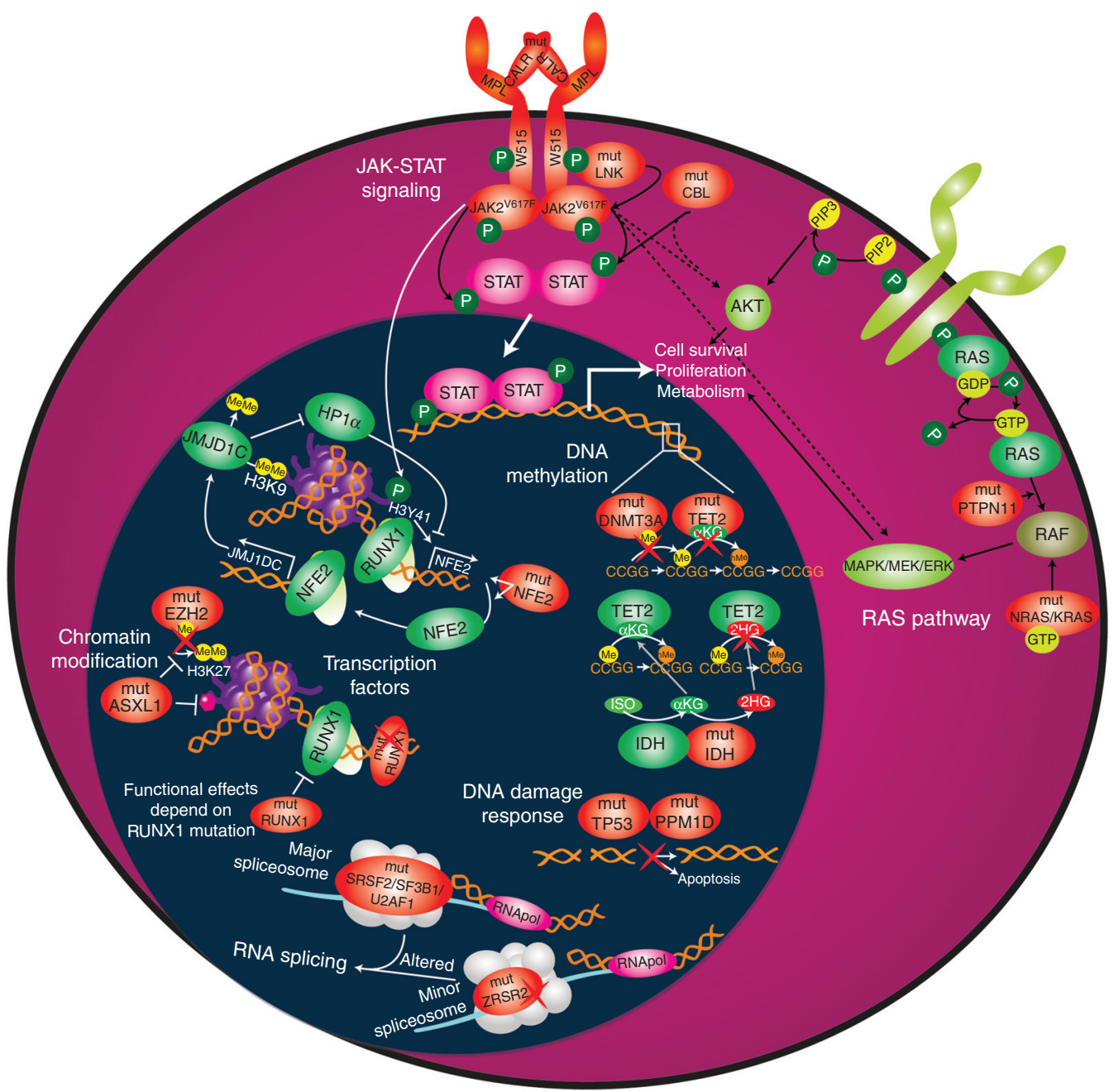

Figure 3. Overview of classes of genes found mutated in myeloproliferative neoplasms (MPNs). This includes (1) DNA methylation (TET2, IDH1, IDH2, and DNMT3A), (2) chromatin modification (ASXL1 and EZH2), (3) RNA splicing (SRSF2, U2AF1, SF3B1, and ZRSR2), (4) JAK-STAT and RAS signaling pathways (JAK2, CALR, MPL, $L N K / S H 2 B 3, C B L, N R A S, K R A S$, and PTPN1), (5) transcription factors (RUNX1 and NFE2), and (6) DNA damage response/stress signaling (TP53 and PPM1D). Wild-type proteins are depicted in green and mutated (mut) proteins are depicted in orange. For illustration, all genes/proteins described in this review are depicted, although some mutations may actually lead to loss of protein expression. (Refer to the main text for detailed explanations of the depicted processes.) $\alpha \mathrm{KG}, \alpha$-ketoglutarate; GDP, guanosine diphosphate; GTP, guanosine triphosphate; $2 \mathrm{HG}$, 2-hydroxyglutarate; hMe, hydroxymethyl; ISO, isocitrate; Me, methyl; P, phosphorylation; PIP2, phosphatidylinositol(4,5)-biphospate; PIP3, phosphatidylinositol(3,4,5)-triphosphate; RNApol, RNA polymerase.

have suggested that TET2 mutations increase the risk of leukemic transformation (AbdelWahab et al. 2010; Beer et al. 2010; Zhang et al. 2012; Lundberg et al. 2014), more recent studies have not consistently seen this association (Tefferi et al. 2016b; Lasho et al. 2018).
TET2 mutations are the most common cooccurring mutation with the JAK2 ${ }^{\mathrm{V} 617 \mathrm{~F}}$ mutation. The order of acquisition of JAK2 and TET2 mutations impacts the MPN phenotype, with JAK2-first patients having a higher probability of presenting with PV than ET and a 
higher risk of thrombosis (Ortmann et al. 2015).

\section{Mouse Models and Affected Cellular Pathways}

In murine and xenograft HSC repopulation studies, Tet2 knockout/knockdown/mutated HSCs have superior HSC repopulation as compared with Tet 2 wild-type cells and JAK $2^{\mathrm{V} 617 \mathrm{~F}+} /$ TET2 knockout/knockdown/mutated cells have superior HSC repopulation as compared with JAK2 ${ }^{\mathrm{V} 617 \mathrm{~F}+}$-only HSCs (Delhommeau et al. 2009; Chen et al. 2015; Kameda et al. 2015b). When comparing JAK2 $2^{\mathrm{V} 617 \mathrm{~F}}$-induced MPN with JAK2 ${ }^{\mathrm{V} 617+}$ Tet2 knockout/knockdown MPN, the later mice developed a more severe form of MPN and had reduced survival (Chen et al. 2015; Kameda et al. 2015b). Proposed mechanisms by which TET2 mutations lead to more severe forms of MPN include epigenetic repression of tumor suppressor genes and increased expression of HSC self-renewal genes possibly due to enhancer hypermethylation (Kameda et al. 2015a; Rasmussen et al. 2015).

\section{IDH1/IDH2}

\section{Consequences of Mutations on Gene Function}

Wild-type isocitrate dehydrogenase $\left(\mathrm{NADP}^{+}\right)$ 1 and 2 (IDH1/IDH2) are metabolic enzymes that catalyze the oxidative decarboxylation of isocitrate to $\alpha \mathrm{KG}$, the cosubstrate for TET proteins. Because of missense mutations in the active catalytic site of IDH (IDH1: R132, IDH2: R140 or R172), IDH proteins acquire the ability to further convert $\alpha \mathrm{KG}$ into 2-hydroxyglutatate (Fig. 3). Besides $\alpha K G, 2$-hydroxyglutatate can also bind TET proteins and the Jumonji family of $\mathrm{H} 3 \mathrm{~K} 9$ and $\mathrm{H} 3 \mathrm{~K} 36$ demethylases (Xu et al. 2011). However, because 2-hydroxyglutatate cannot function as a cosubstrate, it inhibits the function of these enzymes.

\section{Clinical Data}

Missense mutations in $I D H 1$ and IDH 2 occur at low frequencies in MPNs and in 19\%-31\% of
post-MPN AML (Table 1). IDH1/2 mutations have been associated with worse prognosis in ET, and in PMF with a high risk for subsequent transformation to post-MPN sAML (Tefferi et al. 2010, 2016b; Guglielmelli et al. 2014; Yonal-Hindilerden et al. 2016).

\section{Mouse Models and Affected Cellular Pathways}

Like Tet 2 loss, expression of mutant IDH1 causes an expansion of myeloid progenitors in mouse models (Sasaki et al. 2012). Both Jak2 ${ }^{\text {V617F- }}$ only and Jak $2^{\mathrm{V} 617 \mathrm{~F}} / \mathrm{Idh} 2^{\mathrm{R} 140 \mathrm{Q}}$ mice develop a PV phenotype with splenomegaly, but Jak2 $2^{\mathrm{V} 617 \mathrm{~F}} /$ Idh2 ${ }^{\mathrm{R} 140 \mathrm{Q}}$ mice show blast-like cells in the spleen and disruption of splenic architecture that is not observed in Jak2 ${ }^{\mathrm{V} 617 \mathrm{~F}}$-only mice (McKenney et al. 2018a). Overt leukemia was not seen in $\mathrm{Jak} 2^{\mathrm{V} 617 \mathrm{~F}} / \mathrm{Idh} 2^{\mathrm{R} 140 \mathrm{Q}}$ mice, suggesting that additional factors are required to induce leukemic transformation in Jak2 ${ }^{\mathrm{V} 617 \mathrm{~F}}$-expressing mice.

\section{DNMT3A}

\section{Consequences of Mutations on Gene Function}

DNA methyl transferase (DNMT)3A and DNMT3B are de novo methyltransferases as opposed to DNMT1, a maintenance methyltransferase that ensures that DNA methylation is inherited by the daughter cell after cell division. Mutations in DNMT3A in MPN occur as nonsense/frameshift mutations, in addition to missense mutations (including at R882), resulting in reduced methyltransferase activity (Fig. 3) (Ley et al. 2010; Yamashita et al. 2010; AbdelWahab et al. 2011; Emperle et al. 2018). It was suggested that DNMT3A ${ }^{\text {R882mut }}$ acts in a dominant-negative fashion by inhibiting the function and/or oligomerization of wild-type DNMT3A, but recent evidence contradicts this finding (Emperle et al. 2018).

\section{Clinical Data}

DNMT3A mutations are found in 7\% of MPNs, with lower frequency in ET and PV compared 
with (P)MF and post-MPN AML (Table 1). Patients are more likely to present with ET compared with PV or MF when DNMT3A mutations are acquired before JAK2 ${ }^{\mathrm{V} 617 \mathrm{~F}}$ compared with patients who first acquired JAK2 ${ }^{\mathrm{V} 617 \mathrm{~F}}$ (Nangalia et al. 2015).

\section{Mouse Models and Affected Cellular Pathways}

Human DNMT3A/JAK2 and DNMT3A/MPL double-mutant subclones have a growth advantage compared with JAK2 and MPL singlemutant subclones (Rao et al. 2012; Nangalia et al. 2015). This is consistent with in vitro serial replating assays and in vivo CRISPR knockout of Dnmt3a in Jak2 ${ }^{\mathrm{V} 617 \mathrm{~F}}$-expressing mice (Jacquelin et al. 2018). When followed for 32 weeks, mice transplanted with Jak2 ${ }^{\mathrm{V} 617 \mathrm{~F}}$ control HSPCs showed a PV phenotype, whereas recipients receiving Jak2 ${ }^{\mathrm{V} 617 \mathrm{~F}}$ Cas9 Dnmt3a sgRNA HSPCs first developed a PV-like disease, but had progressed into MF by 32 weeks of age (Jacquelin et al. 2018). Mice transplanted with Jak2 ${ }^{\mathrm{V} 617 \mathrm{~F}} / \mathrm{Dnmt3a}$ KO HSPCs showed a marked reduction in long-term and short-term HSCs and a relative accumulation of multipotent progenitors compared with Jak2 ${ }^{\mathrm{V} 617 \mathrm{~F}}$ control recipients (Jacquelin et al. 2018). Mechanistic studies in this model indicate that DNMT3A mutations contribute to MPN progression by deregulating Polycomb repressive complex 2 (PRC2)-mediated gene expression, through enhanced chromatin accessibility at active enhancer sites (Jacquelin et al. 2018).

\section{CHROMATIN MODIFICATION}

\section{ASXL1}

\section{Consequences of Mutations on Gene Function}

Additional sex combs like 1, transcriptional regulator (ASXL1) interacts with several chromatin-modifying proteins, including PRC2. Mutations in ASXL1 are almost exclusively heterozygous nonsense and frameshift mutations in exon 12. There is some controversy regarding the consequences of these mutations on ASXL1 function, which could be loss- or gain-of-function and/or a dominant-negative effect. ASXL1 exon 12 mutants lead to a detectable carboxyterminally truncated protein lacking the plant homology domain (PHD) (Inoue et al. 2016).

\section{Clinical Data}

ASXL1 mutations are more common in PMF (18\%-37\%) and post-MPN AML (17\%-47\%) compared with early-stage MPNs (Table 1) and are associated with poor prognosis in PV and PMF patients (Vannucchi et al. 2013; Guglielmelli et al. 2014; Tefferi et al. 2014, 2016b, 2018b; Lasho et al. 2018). A worse prognosis for ASXL1 mutated patients was also described for PMF patients undergoing allogeneic HSC transplantation (Kröger et al. 2017). Monitoring for acquisition of ASXL1 mutations may be relevant in MPN management, because ASXL1 mutations are the most frequent mutation acquired during ruxolitinib treatment and are associated with the development of leukocytosis and thrombocytopenia (Newberry et al. 2017).

\section{Mouse Models and Affected Cellular Pathways}

ASXL1 mutants missing the PHD domain may not interact with EZH2 (Bera et al. 2012), a member of the PRC2 complex. Consistent with this, ASXL1 mutations modeled by Asxl1 knockdown/knockout contribute to leukemogenesis through derepression of PRC2 targets, such as the Hoxa locus (Fig. 3) (Abdel-Wahab et al. 2012). In an MPN mouse model, Asxll heterozygous knockout cooperated with JAK2 ${ }^{\mathrm{V} 617 \mathrm{~F}}$ to accelerate myelofibrosis and caused leukemia in several mice (Guo et al. 2019). These data show that loss of ASXL1 promotes MPN progression.

To gain insight into mutant Asxl1 as opposed to loss of Asxl1, multiple groups have generated Asxl1 knock-in mice (Hsu et al. 2017; Nagase et al. 2018; Yang et al. 2018; Uni et al. 2019). Several mechanisms have been proposed regarding the effects of mutant ASXL1 on PRC1 and on H2AK119ub (the repressive histone mark that PRC1 deposits) (Asada et al. 2018; Nagase et al. 2018; Uni et al. 2019). In contrast to wild-type ASXL1, mutant ASXL1 binds to the 
PRC1 member, BMI1 (Uni et al. 2019). A wellknown target of BMI1/PRC1 is the p16Ink4a locus, and Ink4a expression is increased in Asxl1-mutant knock-in mice, as a result of inhibition of PRC1 by mutant Asxl1 (Uni et al. 2019). Knockout of p16Ink4a in Asxl1-mutant knock-in mice rescued the decrease in HSC number and increased apoptosis observed in Asxl1-mutant mice, indicating that p16Ink4a plays a key role in Asxl1-mutant-driven leukemogenesis (Uni et al. 2019). Another mechanism by which mutant ASXL1 affects $\mathrm{H} 2 \mathrm{AK} 119 \mathrm{ub}$ is through the de-ubiquitinase (DUB), BAP1. Although mutant ASXL1 interacts less strongly with BAP1 than wild-type ASXL1 (Abdel-Wahab et al. 2012), it has been shown that mutant ASXL1, but not wild-type ASXL1, enhances the catalytic function of the de-ubiquitinase BAP1. This causes a reduction in global H2AK119ub and locally at HOXA and IRF8 loci in HSCs (Scheuermann et al. 2010; Asada et al. 2018). Depletion of BAP1 abrogated mutant ASXL1-induced leukemogenesis, showing that also BAP1 plays a crucial role in Asxl1mutant driven leukemia (Asada et al. 2018).

Mutant ASXL1 has been shown to interact with the acetyl lysine reader bromodomain-containing protein 4 (BRD4) (Yang et al. 2018), which plays an important role in gene transcription and regulation through its interaction with pTEFb and superenhancers. Moreover, HSPCs from transgenic Asxl1-mutant mice are hypersensitive to bromodomain inhibitors (Yang et al. 2018). Amongst others, one important target gene of mutant ASXL1-BRD4 is Prdm16 (Yang et al. 2018), which is critical for the maintenance of HSCs. Finally, another mechanism by which mutant ASXL1 has been reported to contribute to leukemogenesis is through $\mathrm{H} 3 \mathrm{~K}$ and $\mathrm{H} 4 \mathrm{~K}$ deacetylation mediated repression of TGF- $\beta$ (Saika et al. 2018).

\section{$\mathrm{EZH} 2$}

\section{Consequences of Mutations on Gene Function}

Enhancer of zeste homolog 2 (EZH2) is a component of PRC2, which harbors the histone ly- sine $N$-methyltransferase activity of the complex. The most well-studied function of PRC2 is methylation of $\mathrm{H} 3 \mathrm{~K} 27$ and indeed, $\mathrm{H} 3 \mathrm{~K} 27$ levels are reduced in EZH2-mutant cells (Fig. 3). EZH2 can act as tumor suppressor or oncogene depending on the context. Nonsense, frameshift, and missense mutations have been found in MPNs and are thought to be loss-offunction mutations, suggesting that EZH2 acts as a tumor suppressor in MPNs.

\section{Clinical Data}

EZH2 mutations are found in $0 \%-9 \%$ of ET, PV, and PMF patients, and in $13 \%-15 \%$ of postMPN AML (Table 1). EZH2 mutations correlate with a worse clinical phenotype with higher leukocyte counts, blast-cell counts, and larger spleens at diagnosis (Guglielmelli et al. 2011). They were shown to be an independent poor prognostic factor (overall survival 31.6 mo vs. wild-type $137 \mathrm{mo}$ ) (Guglielmelli et al. 2011).

\section{Mouse Models and Affected Cellular Pathways}

Similar to ASXL1, EZH2-inactivating mutations cause derepression of HOXA9, which supports myeloid progenitor cell self-renewal and leukemia development (Khan et al. 2013). In mouse models, concomitant loss of Ezh2 with expression of JAK2 ${ }^{\mathrm{V} 617 \mathrm{~F}}$ leads to enhanced myelofibrosis compared with $\mathrm{JAK} 2^{\mathrm{V} 617 \mathrm{~F}}$ mice, impaired erythroid differentiation, expansion of HSPCs and megakaryocyte progenitors, increased thrombocytosis, and leukocytosis (Shimizu et al. 2016; Yang et al. 2016). However, JAK2 ${ }^{\mathrm{V} 617 \mathrm{~F}} /$ Ezh2 $\mathrm{N}$-methyltransferase -/- $^{-1}$ comutant mice did not develop leukemia, suggesting that additional hits are required for leukemic transformation of JAK2 $2^{\mathrm{V} 617 \mathrm{~F}}$ mice.

\section{RNA SPLICING}

The third class of mutations comprises mutations in genes involved in RNA splicing (Fig. 3). Two types of spliceosomes exist: the major (U2) and minor (U12) spliceosome. The minor spliceosome splices $<1 \%$ of all introns, but these are present (alongside U2-type introns) in 700-800 
genes, and are evolutionarily conserved (Verma et al. 2018). Mutations in RNA splicing factors SF3B1, U2AF1, SRSF2, ZRSR2, SF3A1, PRPF40B, U2AF2, and SF1 have been reported in myeloid malignancies; the first four are most common and will be discussed below. Spliceosomal mutations are typically mutually exclusive with each other, are relatively rare in PV and ET, and occur at higher frequency in PMF (Grinfeld et al. 2018).

\section{SRSF2}

\section{Consequences of Mutations on Gene Function}

The most frequent splicing factor mutations in MPNs are found in serine and arginine rich splicing factor 2 (SRSF2), almost all affecting the hotspot proline at position 95. SRSF2 is involved in recognition of exon splicing enhancers. Whereas wild-type SRSF2 binds the RNA sequences GGNG and CCNG in exon splicing enhancers equally well, P95-mutated SRSF2 preferentially splices exons containing the CCNG sequence (Kim et al. 2015).

\section{Clinical Data}

SRSF2 mutations are infrequent in ET and PV, whereas they occur in $8 \%-22 \%$ of PMF and post-MPN AML (Table 1). Mutations in SRSF2 have consistently been associated with poor prognosis in myeloid malignancies including several types of MPN and post-MPN AML, and have been associated with leukemic transformation (Lasho et al. 2012; Zhang et al. 2012; Vannucchi et al. 2013; Tefferi et al. 2018c,d; Venton et al. 2018).

\section{Mouse Models and Affected Cellular Pathways}

Mutations in SRSF2 cause differential splicing of all classes of splicing events (Kim et al. 2015). Examples include missplicing and nonsensemediated RNA decay-associated down-regulation of EZH2 (Kim et al. 2015) and missplicing of CASP8 causing expression of a truncated CASP8 protein that activates $\mathrm{NF}-\kappa \mathrm{B}$ signaling
(Lee et al. 2018). Expression of mutant SRSF2 causes accumulation of $\mathrm{R}$ loops, replication stress, and activation of the ATR-Chk1 pathway (Chen et al. 2018; Nguyen et al. 2018). Wild-type SRSF2 is able to extract RNA polymerase II carboxy-terminal domain (CTD) kinase from the 7SK complex, which causes transcription pause release (Ji et al. 2013). Mutant SRSF2 loses this ability (Chen et al. 2018), which could explain the accumulation of R loops. Mutant SRSF2 also affects transcriptional regulation through predominant splicing of RUNX1 to form the short RUNX1a transcript over the longer RUNX1b transcript (Sakurai et al. 2017). Besides splicing and transcription, SRSF2 plays a role in regulating DNA stability (Xiao et al. 2007). Consistent with this, whole-exome sequencing of patient samples from different myeloid malignancies showed that SRSF2-mutant samples have more mutations than samples harboring other spliceosome mutations (Yoshida et al. 2011). Data on the role of SRSF2 mutations in MPN pathogenesis and on cooperativity with JAK-STAT activating mutations are needed to better delineate their role in MPNs.

\section{U2AF1}

\section{Consequences of Mutations on Gene Function}

U2 small nuclear RNA auxiliary factor 1 (U2AF1) recognizes the $3^{\prime}$ splice site. U2AF1 contains two mutational hotspot regions (S34 and Q157) located in its two CCCH zinc fingers that are required for RNA binding (Webb and Wise 2004). These mutations alter the preferred -3 (C/A >> T, S34F/Y) or +1 ( G >> A, Q157P) nucleotides flanking the AG of the $3^{\prime}$ splice site (Ilagan et al. 2015).

\section{Clinical Data}

U2AF1 mutations occur in $16 \%$ of PMF and $5 \%-6 \%$ of post-MPN AML patients (Table 1 ). As for SF3B1, PV and ET patients harboring U2AF1 mutations have an inferior myelofibrosis-free survival compared with U2AF1 wildtype patients (Tefferi et al. 2016b). Roughly 
Molecular Genetics of MPNs

$35 \%$ of U2AF1 mutations affect S34 and $65 \%$ affect Q157 or its vicinities (Tefferi et al. 2018a). Only Q157 (and near vicinity) mutations are associated with significantly shorter overall survival in MPNs (Tefferi et al. 2018a).

\section{Mouse Models and Affected Cellular Pathways}

The prognostic difference between S34 and Q157 mutations could be caused by distinct downstream effects. Indeed, besides very few common targets, U2AF1 S34- and Q157-mutant-expressing blood/MDS cells have mostly distinct expression and splicing patterns, with Q157 mutants causing missplicing of, for example, ARID2 and EZH2 (Przychodzen et al. 2013; Ilagan et al. 2015; Park et al. 2016). Like SRSF2 mutations, U2AF1 ${ }^{\mathrm{S} 34}$ mutations cause accumulation of R loops (Q157 mutations not investigated) (Nguyen et al. 2018). Besides this canonical function, U2AF1 has been reported to bind mRNA in the cytoplasm and repress mRNA translation (Palangat et al. 2018). The S34F mutation was suggested to affect translation of hundreds of mRNAs. Whether Q157 mutations affect mRNA translation is currently unknown.

\section{ZRSR2}

\section{Consequences of Mutations on Gene Function}

Zinc finger CCCH-type, RNA binding motif, and serine/arginine-rich 2 (ZRSR2) forms a heterodimer with U2AF2 and is involved in recognizing the $3^{\prime}$ splice site in minor (U12-type) introns, similar to $\mathrm{U} 2 \mathrm{AF} 1$ in the major (U2type) spliceosome. Besides the minor spliceosome, ZRSR2 interacts with major spliceosome components SRSF1/SRSF2 and affects splicing of major introns in vitro, suggesting it also influences the major spliceosome (Shen et al. 2010) and/or other functions of these interaction partners. ZRSR2 is located on the $\mathrm{X}$ chromosome; mutations predominantly occur in males and are frameshift and nonsense mutations in the majority of cases. These data indicate that ZRSR2 mutations are loss-of-function mutations.

\section{Clinical Data}

MPN patients harboring ZRSR2 mutations are more likely to be diagnosed with PMF (Tefferi et al. 2016a) versus ET or PV (Tefferi et al. 2016b; Grinfeld et al. 2018), suggesting that ZRSR2 mutations promote myelofibrotic transformation.

\section{Mouse Models and Affected Cellular Pathways}

In line with a loss-of-function hypothesis and an important role for ZRSR2 in the minor spliceosome, mutations in ZRSR2 predominantly affect splicing of the majority of minor introns, causing intron retention (Madan et al. 2015). Pathways enriched for altered splicing in ZRSR2-mutant MDS cells are enriched for MAPK, ErbB signaling, and genes associated with CML and AML (Madan et al. 2015).

\section{SF3B1}

\section{Consequences of Mutations on Gene Function}

Splicing factor 3b subunit 1 (SF3B1) is part of both the major and minor spliceosome in which it recognizes the BPS as part of the U2 or U11/ U12 snRNPs, respectively. Most mutations are found in exons 14-16, position 700 in particular (K700E). SF3B1 mutations cause alternative $3^{\prime}$ splice site selection.

\section{Clinical Data}

SF3B1 mutations occur in $\sim 9 \%-10 \%$ of PMF and $4 \%-7 \%$ post-MPN AML patients (Table 1). In the context of MPN, SF3B1 mutations most commonly occur in the entity MDS/ MPN with ring sideroblasts and thrombocytosis (MDS/MPN-RS-T). This MDS/MPN overlap syndrome is typically characterized by the presence of both a JAK2 and SF3B1 mutation (Jeromin et al. 2013).

Mouse Models and Affected Cellular Pathways

As in other cancers (Darman et al. 2015; DeBoever et al. 2015; Alsafadi et al. 2016), SF3B1- 
mutated MDS samples mainly had alternative $3^{\prime}$ splice site selection, in many cases leading to nonsense-mediated RNA decay (Lee et al. 2018). Differentially expressed genes included genes involved in RNA processing and metabolism, cell cycle, heme metabolism, and nonsense-mediated decay.

\section{SIGNALING}

\section{LNK}

\section{Consequences of Mutations on Gene Function}

The lymphocyte adaptor protein (LNK) or $\mathrm{SH} 2 \mathrm{~B}$ adapter protein 3 (SH2B3) is an adaptor protein. It interacts with and inhibits signaling through cytokine and tyrosine kinase receptors such as the EPO receptor and the stem cell factor receptor, c-Kit, or kinases like JAK2 (Fig. 3) (Tong et al. 2005; Bersenev et al. 2008; Simon et al. 2008). LNK inhibits the proliferation of HSCs, B-lymphoid cells, and myeloid cells mainly from the erythroid and megakaryocytic lineage (Takaki et al. 2000, 2002; Velazquez et al. 2002). Negative-feedback loops on growth stimulation are perturbed owing to mutations in LNK (and CBL, see below) (Takaki et al. 2002). Many mutations are missense substitutions and target the pleckstrin homology $(\mathrm{PH})$ domain in the majority $(\sim 50 \%)$ of cases.

\section{Clinical Data}

LNK mutations are harbored in $0 \%-9 \%$ of MPN patients and $11 \%$ post-AML patients (Table 1 ). A reduced overall survival has been reported for ET patients harboring $L N K$ mutations (Tefferi et al. 2016b).

\section{Mouse Models and Affected Cellular Pathways}

Mice lacking Lnk developed several characteristics of MPNs, including extramedullary hematopoiesis and splenomegaly, and an increase in HSCs and myeloid progenitor cells, predominantly of the megakaryocytic lineage (Velazquez et al. 2002; Ema et al. 2005; Buza-Vidas et al.
2006; Seita et al. 2007; Bersenev et al. 2008; Takizawa et al. 2008). The SH2 domain of LNK binds nonphosphorylated and $\mathrm{JH} 2$ domainphosphorylated JAK2, thereby inhibiting JAK2 activation (Kurzer et al. 2006; Bersenev et al. 2008; Gery et al. 2009; Baran-Marszak et al. 2010). Additionally, LNK blocks binding of activators with c-Kit and activation of downstream signaling (Takaki et al. 2002; Simon et al. 2008). In addition, LNK can recruit the E3 ubiquitin ligase CBL for degradation of receptors/signaling molecules. These negative-feedback loops on growth stimulation are perturbed owing to mutations in LNK (Takaki et al. 2002). LNK mutations have been shown to enhance growth of JAK2 ${ }^{\mathrm{V} 617 \mathrm{~F}}$ cells in clonogenic assays and in mice (Bersenev et al. 2008; Gery et al. 2009).

\section{CBL}

\section{Consequences of Mutations on Gene Function}

Casitas B-cell lymphoma (CBL) is a RING E3 ubiquitin ligase that promotes $\mathrm{K} 63$ - and $\mathrm{K} 48$ linked ubiquitination (Thien and Langdon 2005; Mohapatra et al. 2013). It recognizes activated (receptor) tyrosine kinases such as epidermal growth factor receptor (EGFR), c-Kit, FLT3, and JAK2 by their phosphorylation and ubiquitinates them, which leads to proteasomal degradation (Thien and Langdon 2005; Mohapatra et al. 2013; Lv et al. 2017). Mutations are mostly homozygous missense substitutions located in the RING and linker domain, significantly reducing the E3 ligase activity, and thus decreasing the degradation of its substrates.

\section{Clinical Data}

Mutations in $\mathrm{CBL}$ are rare in $\mathrm{ET}$ and $\mathrm{PV}$, but occur in up to $6 \%$ of MF and $4 \%$ of post-MPN AML patients (Table 1).

\section{Mouse Models and Affected Cellular Pathways}

CBL mutations lead to increased STAT5 and Akt phosphorylation, cytokine hypersensitivity, and cell proliferation (Sanada et al. 2009). CBL mu- 
Molecular Genetics of MPNs

tations are not merely loss-of-function mutations, because they further augmented cytokine sensitivity found in CBL knockout cells (Sanada et al. 2009).

\section{NRAS/KRAS}

\section{Consequences of Mutations on Gene Function}

Heterozygous missense substitutions at NRAS/ KRAS codons 12, 13, and 61 are most common and favor the GTP-bound state of RAS because of reduced intrinsic GTP hydrolysis and resistance to GAPs (Schubbert et al. 2007). These mutations cause constitutive activation of growth signaling.

\section{Clinical Data}

Mutations in NRAS and KRAS in MPNs are associated with leukemic transformation and have been found in $7 \%-15 \%$ of post-MPN AML patients (Table 1), mutations in NRAS being more frequent than in KRAS.

\section{Mouse Models and Affected Cellular Pathways}

Conditional expression of Kras ${ }^{\mathrm{G} 12 \mathrm{D}}$ in mouse models causes a myeloproliferative disease, whereas the same mutation in Nras causes a much more indolent disease (MacKenzie et al. 1999; Chan and Gilliland 2004).

\section{PTPN11}

\section{Consequences of Mutations on Gene Function}

Protein tyrosine phosphatase, nonreceptor type 11 (PTPN11) is a protein tyrosine phosphatase that acts downstream from several transmembrane receptors and dephosphorylates RAS (Bunda et al. 2015). Mutations in AML target the amino-terminal Src-homology 2 (N-SH2) and phosphotyrosine phosphatase (PTP) domains, which are important for switching between inactive and active forms of PTPN11.

\section{Clinical Data}

Heterozygous missense mutations in PTPN11 are found in $6 \%-8 \%$ of post-MPN AML cases (Table 1) and are associated with shortened survival (Lasho et al. 2018).

Mouse Models and Affected Cellular Pathways

PTPN11 mutations cause a very high phosphatase activity (Tartaglia et al. 2003, 2006; Keilhack et al. 2005; Niihori et al. 2005). Dephosphorylation of RAS increases RAF-RAS association and activation of the RAS-RAF-MEK-ERK pathway (Shi et al. 2000).

\section{TRANSCRIPTION FACTORS}

\section{RUNX1}

\section{Consequences of Mutations on Gene Function}

Runt-related transcription factor 1 (RUNX1) heterodimerizes with core binding factor $\beta$ $(\mathrm{CBF} \beta)$ and regulates key hematopoietic transcriptional programs. It contains a DNA-binding and nuclear localizing Runt homology domain (RHD). Missense, frameshift, and nonsense mutations inactivate the affected RUNX1 protein, and, in addition, mutant RUNX1 may act in a dominant-negative way over the remaining wild-type RUNX1 protein.

\section{Clinical Data}

RUNX1 mutations occur in $4 \%-13 \%$ of postMPN AML patients (Table 1). Multivariate analysis showed significantly shortened survival for RUNX1 mutated versus RUNX1 wild-type post-MPN AML patients (Lasho et al. 2018; McNamara et al. 2018).

\section{Mouse Models and Affected Cellular Pathways}

RUNX1 inactivation contributes to AML development through reduced myeloid differentiation and increased HSC self-renewal. The most frequent dominant-negative mutation, $\mathrm{D} 171 \mathrm{~N}$, is located in its DNA-binding RHD. Mice trans- 
planted with bone marrow cells overexpressing RUNX1 $^{\text {D171N }}$ developed MDS and MDS/AML within 4-13 mo after transplantation (Watanabe-Okochi et al. 2008). Ectopic expression of RUNX1 ${ }^{\mathrm{D} 171 \mathrm{~N}}$ in $\mathrm{CD} 34^{+}$HSPCs from chronic phase MPN patients seemed to keep the cells in a HSPC state and increase proliferation (Ding et al. 2009). Besides mutations in RUNX1, the short RUNX1a isoform has been shown to be overexpressed in MPN (Sakurai et al. 2017). As is the case for many leukemia-associated RUNX1 mutations, RUNX1a has been proposed to act in a dominant-negative way over the other two isoforms RUXN1b and RUNX1c. RUNX1a expression causes expansion of murine HSCs and up-regulates Hoxa9, Meis1, and Stat1 (Tsuzuki and Seto 2012; Ran et al. 2013).

\section{NFE2}

\section{Consequences of Mutations on Gene Function}

A 4-amino acid in-frame deletion and frameshift mutations leading to expression of a carboxy-terminally truncated protein have been found in the transcription factor nuclear factor, erythroid 2 (NFE2) in MPNs. The mutations caused increased mRNA and protein expression of wild-type NFE2 (Jutzi et al. 2013).

\section{Clinical Data}

Mutations in NFE2 are carried by $0 \%-3 \%$ of PV and MF patients (Table 1).

\section{Mouse Models and Affected Cellular Pathways}

Mice transplanted with ectopically expressing mutant NF-E2 bone marrow cells had elevated myeloid progenitor cells as well as platelet numbers, erythrocyte numbers, and absolute neutrophil counts compared with control mice (Jutzi et al. 2013). When combined with JAK2 ${ }^{\text {V617F }}$ JAK2 $2^{\mathrm{V} 617 \mathrm{~F}} / \mathrm{NFE} 2$ comutant mice had elevated hemoglobin and white blood cell count compared with JAK2 ${ }^{\mathrm{V} 617 \mathrm{~F}}$ mice (Jutzi et al. 2013). These data show that mutant NFE2 promotes myelopoiesis and augments the JAK2 $2^{\mathrm{V} 617 \mathrm{~F}}$-in- duced MPN phenotype. Besides mutated NFE2, increased expression of NFE2 has been found in MPN patient samples. One of the proposed mechanisms for elevated NFE2 expression includes JAK2-dependent phosphorylation of H3Y41 in the NFE2 promoter, leading to decreased binding of the repressive $\mathrm{HP} 1 \alpha$ protein (Peeken et al. 2018). Increased NFE2 expression causes elevated transcription of the histone demethylase JMJD1C. In turn, JMJD1C causes positive feedback through decreasing $\mathrm{H} 3 \mathrm{~K} 9 \mathrm{me} 2$ on the NFE2 promoter, also reducing HP1 $\alpha$ binding and increasing NFE2 expression (Fig. 3) (Peeken et al. 2018).

\section{DNA DAMAGE RESPONSE/STRESS SIGNALING}

\section{TP53}

\section{Consequences of Mutations on Gene Function}

The last class of genes found mutated in MPNs includes genes involved in the DNA damage response and cellular stress. Tumor protein P53 (TP53) is a transcription factor frequently mutated in cancer. It is essential for a proper cellular response to stress and DNA damage. Many TP53 mutations are missense mutations, which cause an abundance of mutant TP53 protein compared with wild-type TP53 (Rotter 1983). TP53 is a tumor suppressor, and TP53 mutations can have several (nonmutually exclusive) effects: (1) loss of tumor suppressor function, (2) dominant-negative effect on wild-type TP53 protein, and (3) gain of functions that the wild-type protein does not possess.

\section{Clinical Data}

Mutations in TP53 are uncommon in chronic phase MPNs, but exist in $11 \%-36 \%$ of postMPN AML patients (Table 1). In addition to higher mutational frequency, the variant allele fraction of mutant TP53 is higher in patient samples from transformed patients compared with chronic phase samples (Rampal et al. 2014). These data suggest that TP53 mutations contribute to leukemic transformation in MPN. 
Post-MPN AML patients harboring TP53 mutations have an inferior overall survival compared with wild-type patients (mutant $4.4 \mathrm{mo}$ vs. wild-type $6.5 \mathrm{mo}$ ) (Lundberg et al. 2014; Venton et al. 2018).

\section{Mouse Models and Affected Cellular Pathways}

In line with patient data, the concomitant knockout of Tp53 and expression of JAK2 ${ }^{\mathrm{V} 617 \mathrm{~F}}$ leads to leukemic transformation in mouse models (Rampal et al. 2014). Several progenitor populations from these mice were able to induce leukemia in (secondary) recipients. It has been shown that TP53 mutations contribute to AML by increasing HSC self-renewal and resistance to cellular stress (Liu et al. 2009).

\section{PPM1D}

\section{Consequences of Mutations on Gene Function}

The serine-threonine Protein Phosphatase $\mathrm{Mg}^{+}$/ $M n 2^{+} 1 D(P P M 1 D)$ gene is transcriptionally upregulated on TP53 induction in response to DNA damage (Fiscella et al. 1997) and in turn negatively regulates TP53 and other proteins involved in the DNA damage response. Truncating and frameshift PPM1D mutations in exon 6 have been found in clonal hematopoiesis, MDS, and MPNs (Genovese et al. 2014; Xie et al. 2014; Coombs et al. 2017; Lindsley et al. 2017).

\section{Clinical Data}

PPM1D was recently described to be mutated in MPNs, with $1.9 \%$ of patients affected (Table 1; Grinfeld et al. 2018). Interestingly, PPM1D mutations are more frequent in patients who have been exposed to chemotherapy and who were diagnosed with therapy-related myeloid neoplasms (Ruark et al. 2013; Zhang et al. 2014; Kahn et al. 2018).

\section{Mouse Models and Affected Cellular Pathways}

PPM1D exon 6 mutations cause expression of a truncated PPM1D protein that lacks a carboxy- terminal degradation domain (Kahn et al. 2018). Consistent with patient data, PPM1D-mutant cells are selected for when treated with chemotherapy (Hsu et al. 2018; Kahn et al. 2018). This is explained by an abrogated DNA damage response, causing altered cell cycle progression, decreased apoptosis, and reduced mitochondrial priming in PPM1D-mutant compared with control cells (Kahn et al. 2018).

\section{THERAPEUTIC IMPLICATIONS}

Although the molecular pathogenesis of MPNs has been comprehensively defined, there are currently no curative pharmacological treatment options. The MPN phenotypic driver mutations represent attractive therapeutic targets because they are disease-initiating, activating, and can occur as the sole mutation, particularly in PV and ET. The main deficiency of JAK2 inhibitors is an absence of clonal selectivity, and efforts are ongoing to develop JAK2V617F-mutant-specific inhibitors. Mutant CALR also represents an enticing therapeutic target in MPNs, particularly from an immunological perspective, given its shared mutant-specific carboxy-terminal peptide.

Almost all of the concomitant mutations seen in MPNs do not currently have rationally designed approaches to target them, with IDH1/ 2 being the rare exception. Two drugs that inhibit mutant IDH1 or mutant IDH2 have been approved for the treatment of adult refractory or relapsed AML in the past 2 years: ivosidemib and enasidenib, respectively. Because mutations in IDH proteins are associated with a high risk of leukemic transformation in MPN, this is an important clinical development. Spliceosomal mutations, in particular SRSF2 mutations, are another class of mutations associated with disease progression in MPNs, and there has been great enthusiasm around the development of spliceosomal inhibitors in myeloid malignancies more broadly. However, early clinical trial data in myelodysplastic syndrome (MDS) indicates an absence of clonal selectivity for spliceosomal inhibitors, although further studies are needed.

Another challenge posed by the genomic complexity of MPNs is that even drugs with 
potent, on-target, mutant-specific activity may have limited clinical efficacy depending on the clonal architecture of the MPNs (e.g., targeting a subclonal mutation as compared with a truncal lesion). Treatment paradigms that invoke early intervention to target disease-initiating genetic events and therapeutic approaches with broad efficacy regardless of molecular genetics (e.g., immunotherapy) are attractive for this reason.

\section{CONCLUDING REMARKS}

MPN phenotypic driver mutations that activate JAK-STAT signaling are central to MPN pathogenesis. However, concomitant somatic mutations are common and are often associated with disease progression. With the integration of NGS panels into MPN clinical care, molecular genetics is increasingly being used to predict prognosis and estimate the risk of disease progression (e.g., to AML) (Grinfeld et al. 2018). In myelofibrosis, clinical prognostic models that include molecular genetic parameters have already been developed (Ciboddo and Mullally 2018). The prognostic significance of concomitant somatic mutations in ET and PV is starting to be explored (Tefferi et al. 2016b; Grinfeld et al. 2018). With these advances, we have seen the development of novel mouse models to study the effects of concomitant mutations on MPN stem cells (Jacquelin et al. 2018; McKenney et al. 2018b) and identify the mechanisms by which these mutations drive disease progression. The next step is to use this knowledge to develop novel treatment approaches that exploit molecular vulnerabilities and preferentially target MPN stem cells in patients.

\section{COMPETING INTEREST STATEMENT}

The authors have declared that no conflict of interest exists.

\section{ACKNOWLEDGMENTS}

This work was supported by the National Institutes of Health (NIH) (R01HL131835 to A.M.), the MPN Research Foundation (A.M.), and the Gabrielle's Angel Foundation for Cancer
Research (A.M.). A.M. is a Scholar of The Leukemia \& Lymphoma Society. A.E.M. is supported by the European Molecular Biology Organization (EMBO) Long-Term Fellowship 2017-268.

\section{REFERENCES}

Abdel-Wahab O, Manshouri T, Patel J, Harris K, Yao J, Hedvat C, Heguy A, Bueso-Ramos C, Kantarjian H, Levine RL, et al. 2010. Genetic analysis of transforming events that convert chronic myeloproliferative neoplasms to leukemias. Cancer Res 70: 447-452. doi:10.1158/00085472.CAN-09-3783

Abdel-Wahab O, Pardanani A, Rampal R, Lasho TL, Levine RL, Tefferi A. 2011. DNMT3A mutational analysis in primary myelofibrosis, chronic myelomonocytic leukemia and advanced phases of myeloproliferative neoplasms. Leukemia 25: 1219-1220. doi:10.1038/leu.2011.82

Abdel-Wahab O, Adli M, LaFave LM, Gao J, Hricik T, Shih AH, Pandey S, Patel JP, Chung YR, Koche R, et al. 2012. ASXL1 mutations promote myeloid transformation through loss of PRC2-mediated gene repression. Cancer Cell 22: 180-193. doi:10.1016/j.ccr.2012.06.032

Alsafadi S, Houy A, Battistella A, Popova T, Wassef M, Henry E, Tirode F, Constantinou A, Piperno-Neumann S, Roman-Roman S, et al. 2016. Cancer-associated SF3B1 mutations affect alternative splicing by promoting alternative branchpoint usage. Nat Commun 7: 10615. doi:10 .1038/ncomms 10615

Angona A, Fernández-Rodríguez C, Alvarez-Larrán A, Camacho L, Longarón R, Torres E, Pairet S, Besses C, Bellosillo B. 2016. Molecular characterisation of triple negative essential thrombocythaemia patients by platelet analysis and targeted sequencing. Blood Cancer J 6: e463. doi:10 $.1038 /$ bcj.2016.75

Asada S, Goyama S, Inoue D, Shikata S, Takeda R, Fukushima T, Yonezawa T, Fujino T, Hayashi Y, Kawabata KC, et al. 2018. Mutant ASXL1 cooperates with BAP1 to promote myeloid leukaemogenesis. Nat Commun 9: 2733. doi:10.1038/s41467-018-05085-9

Baran-Marszak F, Magdoud H, Desterke C, Alvarado A, Roger C, Harel S, Mazoyer E, Cassinat B, Chevret S, Tonetti C, et al. 2010. Expression level and differential JAK2-V617F-binding of the adaptor protein Lnk regulates JAK2-mediated signals in myeloproliferative neoplasms. Blood 116: 5961-5971. doi:10.1182/blood-200912-256768

Beer PA, Delhommeau F, LeCouedic JP, Dawson MA, Chen E, Bareford D, Kusec R, McMullin MF, Harrison CN, Vannucchi AM, et al. 2010. Two routes to leukemic transformation after a JAK2 mutation-positive myeloproliferative neoplasm. Blood 115: 2891-2900. doi:10.1182/ blood-2009-08-236596

Bera R, Liang D, Chiu M, Huang Y, Liang S, Shih L. 2012. PHD domain deletion mutations of ASXL1 promote myeloid leukemia transformation through epigenetic dysregulation and inhibit megakaryocytic differentiation through the inactivation of FOSB in K562 cells. Presented 
at the American Society of Hematology Conference. Atlanta, 8-11 December 2012.

Bersenev A, Wu C, Balcerek J, Tong W. 2008. Lnk controls mouse hematopoietic stem cell self-renewal and quiescence through direct interactions with JAK2. J Clin Invest 118: $2832-2844$.

Bunda S, Burrell K, Heir P, Zeng L, Alamsahebpour A, Kano Y, Raught B, Zhang ZY, Zadeh G, Ohh M. 2015. Inhibition of SHP2-mediated dephosphorylation of Ras suppresses oncogenesis. Nat Commun 6: 8859. doi:10.1038/ ncomms 9859

Buza-Vidas N, Antonchuk J, Qian H, Mansson R, Luc S, Zandi S, Anderson K, Takaki S, Nygren JM, Jensen CT, et al. 2006. Cytokines regulate postnatal hematopoietic stem cell expansion: Opposing roles of thrombopoietin and LNK. Genes Dev 20: 2018-2023. doi:10.1101/gad .385606

Chan IT, Gilliland DG. 2004. Oncogenic K-ras in mouse models of myeloproliferative disease and acute myeloid leukemia. Cell Cycle 3: 536-537. doi:10.4161/cc.3.5.828

Chen E, Mullally A. 2014. How does JAK2V617F contribute to the pathogenesis of myeloproliferative neoplasms? $\mathrm{He}$ matology 2014: 268-276. doi:10.1182/asheducation-2014 .1 .268

Chen E, Schneider RK, Breyfogle LJ, Rosen EA, Poveromo L, Elf S, Ko A, Brumme K, Levine R, Ebert BL, et al. 2015. Distinct effects of concomitant Jak2V617F expression and Tet2 loss in mice promote disease progression in myeloproliferative neoplasms. Blood 125: 327-335. doi:10.1182/blood-2014-04-567024

Chen L, Chen JY, Huang YJ, Gu Y, Qiu J, Qian H, Shao C, Zhang X, Hu J, Li H, et al. 2018. The augmented R-loop is a unifying mechanism for myelodysplastic syndromes induced by high-risk splicing factor mutations. Mol Cell 69: 412-425.e6. doi:10.1016/j.molcel.2017.12.029

Ciboddo M, Mullally A. 2018. JAK2 (and other genes) be nimble with MPN diagnosis, prognosis, and therapy. $\mathrm{He}$ matology 2018: 110-117. doi:10.1182/asheducation-2018 .1 .110

Coombs CC, Zehir A, Devlin SM, Kishtagari A, Syed A, Jonsson P, Hyman DM, Solit DB, Robson ME, Baselga J, et al. 2017. Therapy-related clonal hematopoiesis in patients with non-hematologic cancers is common and associated with adverse clinical outcomes. Cell Stem Cell 21: 374-382.e4. doi:10.1016/j.stem.2017.07.010

Darman RB, Seiler M, Agrawal AA, Lim KH, Peng S, Aird D, Bailey SL, Bhavsar EB, Chan B, Colla S, et al. 2015. Cancer-associated SF3B1 hotspot mutations induce cryptic $3^{\prime}$ splice site selection through use of a different branch point. Cell Rep 13: 1033-1045. doi:10.1016/j.celrep.2015 .09 .053

DeBoever C, Ghia EM, Shepard PJ, Rassenti L, Barrett CL, Jepsen K, Jamieson CH, Carson D, Kipps TJ, Frazer KA. 2015. Transcriptome sequencing reveals potential mechanism of cryptic $3^{\prime}$ splice site selection in SF3B1-mutated cancers. PLoS Comput Biol 11: e1004105. doi:10.1371/ journal.pcbi.1004105

Delhommeau F, Dupont S, Della Valle V, James C, Trannoy S, Massé A, Kosmider O, Le Couedic JP, Robert F, Alberdi A, et al. 2009. Mutation in TET2 in myeloid cancers. $N$ Engl J Med 360: 2289-2301. doi:10.1056/NEJ Moa0810069
Ding Y, Harada Y, Imagawa J, Kimura A, Harada H. 2009 AML1/RUNX1 point mutation possibly promotes leukemic transformation in myeloproliferative neoplasms. Blood 114: 5201-5205. doi:10.1182/blood-2009-06223982

Dunbar AJ, Gondek LP, O’Keefe CL, Makishima H, Rataul MS, Szpurka H, Sekeres MA, Wang XF, McDevitt MA, Maciejewski JP. 2008. 250K single nucleotide polymorphism array karyotyping identifies acquired uniparental disomy and homozygous mutations, including novel missense substitutions of c-Cbl, in myeloid malignancies. Cancer Res 15: 10349-10357. doi:10.1158/0008-5472 .CAN-08-2754

Elf S, Abdelfattah NS, Chen E, Perales-Paton J, Rosen EA, Ko A, Peisker F, Florescu N, Giannini S, Wolach O, et al 2016. Mutant calreticulin requires both its mutant C-terminus and the thrombopoietin receptor for oncogenic transformation. Cancer Discov 6: 368-381. doi:10.1158/ 2159-8290.CD-15-1434

Ema H, Sudo K, Seita J, Matsubara A, Morita Y, Osawa M, Takatsu K, Takaki S, Nakauchi H. 2005. Quantification of self-renewal capacity in single hematopoietic stem cells from normal and Lnk-deficient mice. Dev Cell 8: 907914. doi:10.1016/j.devcel.2005.03.019

Emperle M, Dukatz M, Kunert S, Holzer K, Rajavelu A, Jurkowska RZ, Jeltsch A. 2018. The DNMT3A R882H mutation does not cause dominant negative effects in purified mixed DNMT3A/R882H complexes. Sci Rep 8: 13242. doi:10.1038/s41598-018-31635-8

Fiscella M, Zhang H, Fan S, Sakaguchi K, Shen S, Mercer WE, Vande Woude GF, O'Connor PM, Appella E. 1997. Wip1, a novel human protein phosphatase that is induced in response to ionizing radiation in a p53-dependent manner. Proc Natl Acad Sci 94: 6048-6053. doi:10 $.1073 /$ pnas.94.12.6048

Genovese G, Kähler AK, Handsaker RE, Lindberg J, Rose SA, Bakhoum SF, Chambert K, Mick E, Neale BM, Fromer M, et al. 2014. Clonal hematopoiesis and blood-cancer risk inferred from blood DNA sequence. N Engl J Med 371: 2477-2487. doi:10.1056/NEJMoa1409405

Gery S, Cao Q, Gueller S, Xing H, Tefferi A, Koeffler HP. 2009. Lnk inhibits myeloproliferative disorder-associated JAK2 mutant, JAK2V617F. J Leukoc Biol 85: 957-965. doi:10.1189/jlb.0908575

Gibson CJ, Steensma DP. 2018. New Insights from studies of clonal hematopoiesis. Clin Cancer Res 24: 4633-4642. doi:10.1158/1078-0432.CCR-17-3044

Grand FH, Hidalgo-Curtis CE, Ernst T, Zoi K, Zoi C, McGuire C, Kreil S, Jones A, Score J, Metzgeroth G, et al. 2009. Frequent CBL mutations associated with $11 \mathrm{q}$ acquired uniparental disomy in myeloproliferative neoplasms. Blood 113: 6182-6192. doi:10.1182/blood-200812-194548

Grinfeld J, Nangalia J, Baxter EJ, Wedge DC, Angelopoulos N, Cantrill R, Godfrey AL, Papaemmanuil E, Gundem G, MacLean C, et al. 2018. Classification and personalized prognosis in myeloproliferative neoplasms. $N$ Engl J Med 379: 1416-1430. doi:10.1056/NEJMoa1716614

Guglielmelli P, Biamonte F, Score J, Hidalgo-Curtis C, Cervantes F, Maffioli M, Fanelli T, Ernst T, Winkelman N, Jones AV, et al. 2011. EZH2 mutational status predicts 
A.E. Marneth and A. Mullally

poor survival in myelofibrosis. Blood 118: $5227-5234$ doi:10.1182/blood-2011-06-363424

Guglielmelli P, Lasho TL, Rotunno G, Score J, Mannarelli C Pancrazzi A, Biamonte F, Pardanani A, Zoi K, Reiter A, et al. 2014. The number of prognostically detrimental mutations and prognosis in primary myelofibrosis: An international study of 797 patients. Leukemia 28: 1804-1810. doi:10.1038/leu.2014.76

Guglielmelli P, Lasho TL, Rotunno G, Mudireddy M, Mannarelli C, Nicolosi M, Pacilli A, Pardanani A, Rumi E, Rosti V, et al. 2018. MIPSS70: Mutation-enhanced international prognostic score system for transplantation-age patients with primary myelofibrosis. J Clin Oncol 36: 310318. doi:10.1200/JCO.2017.76.4886

Guo Y, Zhou Y, Yamatomo S, Yang H, Zhang P, Chen S, Nimer SD, Zhao ZJ, Xu M, Bai J, et al. 2019. ASXL1 alteration cooperates with $J A K 2 V 617 F$ to accelerate myelofibrosis. Leukemia 33: 1287-1291. doi:10.1038/s41375018-0347-y

Harutyunyan A, Klampfl T, Cazzola M, Kralovics R. 2011. p53 lesions in leukemic transformation. NEng J Med 364: 488-490. doi:10.1056/NEJMc1012718

Hinds DA, Barnholt KE, Mesa RA, Kiefer AK, Do CB, Eriksson N, Mountain JL, Francke U, Tung JY, Nguyen HM et al. 2016. Germ line variants predispose to both JAK2 V617F clonal hematopoiesis and myeloproliferative neoplasms. Blood 128: 1121-1128. doi:10.1182/blood-201506-652941

Hsu YC, Chiu YC, Lin CC, Kuo YY, Hou HA, Tzeng YS, Kao CJ, Chuang PH, Tseng MH, Hsiao TH, et al. 2017. The distinct biological implications of Asxll mutation and its roles in leukemogenesis revealed by a knock-in mouse model. J Hematol Oncol 10: 139. doi:10.1186/s13045017-0508-x

Hsu JI, Dayaram T, Tovy A, De Braekeleer E, Jeong M, Wang F, Zhang J, Heffernan TP, Gera S, Kovacs JJ, et al. 2018. PPM1D mutations drive clonal hematopoiesis in response to cytotoxic chemotherapy. Cell Stem Cell 23: 700-713.e6. doi:10.1016/j.stem.2018.10.004

Ilagan JO, Ramakrishnan A, Hayes B, Murphy ME, Zebari AS, Bradley P, Bradley RK. 2015. U2AF1 mutations alter splice site recognition in hematological malignancies. $G e$ nome Res 25: 14-26. doi:10.1101/gr.181016.114

Inoue D, Matsumoto M, Nagase R, Saika M, Fujino T, Nakayama KI, Kitamura T. 2016. Truncation mutants of ASXL1 observed in myeloid malignancies are expressed at detectable protein levels. Exp Hematol 44: 172-176.e1. doi:10.1016/j.exphem.2015.11.011

Jacquelin S, Straube J, Cooper L, Vu T, Song A, Bywater M Baxter E, Heidecker M, Wackrow B, Porter A, et al. 2018. Jak2V617F and Dnmt3a loss cooperate to induce myelofibrosis through activated enhancer-driven inflammation. Blood 132: 2707-2721. doi:10.1182/blood-2018-04846220

Jaiswal S, Fontanillas P, Flannick J, Manning A, Grauman PV, Mar BG, Lindsley RC, Mermel CH, Burtt N, Chavez A, et al. 2014. Age-related clonal hematopoiesis associated with adverse outcomes. N Engl J Med 371: 2488-2498. doi:10.1056/NEJMoa1408617

Jaiswal S, Natarajan P, Silver AJ, Gibson CJ, Bick AG, Shvartz E, McConkey M, Gupta N, Gabriel S, Ardissino D, et al. 2017. Clonal hematopoiesis and risk of atherosclerotic cardiovascular disease. N Engl J Med 377: 111-121. doi:10.1056/NEJMoa1701719

Jeromin S, Haferlach T, Grossmann V, Alpermann T, Kowarsch A, Haferlach C, Kern W, Schnittger S. 2013. High frequencies of $S F 3 B 1$ and JAK2 mutations in refractory anemia with ring sideroblasts associated with marked thrombocytosis strengthen the assignment to the category of myelodysplastic/myeloproliferative neoplasms. Haematologica 98: e15-e17. doi:10.3324/haematol.2012 .072538

Ji X, Zhou Y, Pandit S, Huang J, Li H, Lin CY, Xiao R, Burge CB, Fu XD. 2013. SR proteins collaborate with 7SK and promoter-associated nascent RNA to release paused polymerase. Cell 153: 855-868. doi:10.1016/j.cell.2013.04 .028

Jutzi JS, Bogeska R, Nikoloski G, Schmid CA, Seeger TS, Stegelmann F, Schwemmers S, Gründer A, Peeken JC, Gothwal M, et al. 2013. MPN patients harbor recurrent truncating mutations in transcription factor NF-E2.J Exp Med 210: 1003-1019. doi:10.1084/jem.20120521

Kahn JD, Miller PG, Silver AJ, Sellar RS, Bhatt S, Gibson C, McConkey M, Adams D, Mar B, Mertins P, et al. 2018. PPM1D-truncating mutations confer resistance to chemotherapy and sensitivity to PPM1D inhibition in hematopoietic cells. Blood 132: 1095-1105. doi:10.1182/ blood-2018-05-850339

Kameda T, Shide K, Yamaji T, Kamiunten A, Sekine M, Hidaka T, Kubuki Y, Sashida G, Aoyama K, Yoshimitsu M, et al. 2015a. Gene expression profiling of loss of TET2 and/or JAK2V617F mutant hematopoietic stem cells from mouse models of myeloproliferative neoplasms. Genom Data 4: 102-108. doi:10.1016/j.gdata.2015.04.002

Kameda T, Shide K, Yamaji T, Kamiunten A, Sekine M, Taniguchi Y, Hidaka T, Kubuki Y, Shimoda H, Marutsuka $\mathrm{K}$, et al. 2015b. Loss of TET2 has dual roles in murine myeloproliferative neoplasms: Disease sustainer and disease accelerator. Blood 125: 304-315. doi:10.1182/blood2014-04-555508

Keilhack H, David FS, McGregor M, Cantley LC, Neel BG. 2005. Diverse biochemical properties of Shp2 mutants. Implications for disease phenotypes. J Biol Chem 280: 30984-30993. doi:10.1074/jbc.M504699200

Khan SN, Jankowska AM, Mahfouz R, Dunbar AJ, Sugimoto Y, Hosono N, Hu Z, Cheriyath V, Vatolin S, Przychodzen $\mathrm{B}$, et al. 2013. Multiple mechanisms deregulate EZH2 and histone $\mathrm{H} 3$ lysine 27 epigenetic changes in myeloid malignancies. Leukemia 27: 1301-1309. doi:10.1038/leu .2013 .80

Kim E, Ilagan JO, Liang Y, Daubner GM, Lee SC, Ramakrishnan A, Li Y, Chung YR, Micol JB, Murphy ME, et al 2015. SRSF2 mutations contribute to myelodysplasia by mutant-specific effects on exon recognition. Cancer Cell 27: 617-630. doi:10.1016/j.ccell.2015.04.006

Klampfl T, Gisslinger H, Harutyunyan AS, Nivarthi H, Rumi E, Milosevic JD, Them NC, Berg T, Gisslinger B, Pietra D, et al. 2013. Somatic mutations of calreticulin in myeloproliferative neoplasms. N Engl J Med 369: 2379-2390. doi:10.1056/NEJMoa1311347

Kröger N, Panagiota V, Badbaran A, Zabelina T, Triviai I, Araujo Cruz MM, Shahswar R, Ayuk F, Gehlhaar M, Wolschke C, et al. 2017. Impact of molecular genetics on outcome in myelofibrosis patients after allogeneic 
stem cell transplantation. Biol Blood Marrow Transplant 23: 1095-1101. doi:10.1016/j.bbmt.2017.03.034

Kurzer JH, Saharinen P, Silvennoinen O, Carter-Su C. 2006. Binding of SH2-B family members within a potential negative regulatory region maintains JAK2 in an active state. Mol Cell Biol 26: 6381-6394. doi:10.1128/MCB .00570-06

Lasho TL, Jimma T, Finke CM, Patnaik M, Hanson CA, Ketterling RP, Pardanani A, Tefferi A. 2012. SRSF2 mutations in primary myelofibrosis: Significant clustering with $I D H$ mutations and independent association with inferior overall and leukemia-free survival. Blood 120: 4168-4171. doi:10.1182/blood-2012-05-429696

Lasho TL, Mudireddy M, Finke CM, Hanson CA, Ketterling RP, Szuber N, Begna KH, Patnaik MM, Gangat N, Pardanani A, et al. 2018. Targeted next-generation sequencing in blast phase myeloproliferative neoplasms. Blood $A d v 2$ : 370-380. doi:10.1182/bloodadvances.2018015875

Lee SC, North K, Kim E, Jang E, Obeng E, Lu SX, Liu B, Inoue D, Yoshimi A, Ki M, et al. 2018. Synthetic lethal and convergent biological effects of cancer-associated spliceosomal gene mutations. Cancer Cell 34: 225-241.e8. doi:10 $.1016 /$ j.ccell.2018.07.003

Ley TJ, Ding L, Walter MJ, McLellan MD, Lamprecht T, Larson DE, Kandoth C, Payton JE, Baty J, Welch J, et al. 2010. DNMT3A mutations in acute myeloid leukemia. $N$ Engl $J$ Med 363: 2424-2433. doi:10.1056/NEJ Moa1005143

Li J, Prins D, Park HJ, Grinfeld J, Gonzalez-Arias C, Loughran S, Dovey OM, Klampfl T, Bennett C, Hamilton TL, et al. 2018. Mutant calreticulin knockin mice develop thrombocytosis and myelofibrosis without a stem cell self-renewal advantage. Blood 131: 649-661. doi:10 .1182/blood-2017-09-806356

Lin J, Yao DM, Qian J, Chen Q, Qian W, Li Y, Yang J, Wang CZ, Chai HY, Qian Z, Xiao GF, Xu WR. 2011. Recurrent DNMT3A R882 mutations in Chinese patients with acute myeloid leukemia and myelodysplastic syndrome. PLoS ONE 6: e26906. doi:10.1371/journal.pone.0026906

Lindsley RC, Saber W, Mar BG, Redd R, Wang T, Haagenson MD, Grauman PV, Hu ZH, Spellman SR, Lee SJ, et al. 2017. Prognostic mutations in myelodysplastic syndrome after stem-cell transplantation. $N$ Engl J Med 376: 536547. doi:10.1056/NEJMoa1611604

Liu Y, Elf SE, Miyata Y, Sashida G, Liu Y, Huang G, Di Giandomenico S, Lee JM, Deblasio A, Menendez S, et al. 2009. p53 regulates hematopoietic stem cell quiescence. Cell Stem Cell 4: 37-48. doi:10.1016/j.stem.2008 .11 .006

Lundberg P, Karow A, Nienhold R, Looser R, Hao-Shen H, Nissen I, Girsberger S, Lehmann T, Passweg J, Stern M, et al. 2014. Clonal evolution and clinical correlates of somatic mutations in myeloproliferative neoplasms. Blood 123: 2220-2228. doi:10.1182/blood-2013-11-537167

Lv K, Jiang J, Donaghy R, Riling CR, Cheng Y, Chandra V, Rozenova K, An W, Mohapatra BC, Goetz BT, et al. 2017. CBL family E3 ubiquitin ligases control JAK2 ubiquitination and stability in hematopoietic stem cells and myeloid malignancies. Genes Dev 31: 1007-1023. doi:10.1101/gad .297135 .117

MacKenzie KL, Dolnikov A, Millington M, Shounan Y, Symonds G. 1999. Mutant N-ras induces myeloproliferative disorders and apoptosis in bone marrow repopulated mice. Blood 93: 2043-2056.

Madan V, Kanojia D, Li J, Okamoto R, Sato-Otsubo A, Kohlmann A, Sanada M, Grossmann V, Sundaresan J, Shiraishi Y, et al. 2015. Aberrant splicing of U12type introns is the hallmark of ZRSR2 mutant myelodysplastic syndrome. Nat Commun 6: 6042. doi:10.1038/ ncomms7042

Makishima H, Cazzolli H, Szpurka H, Dunbar A, Tiu R, Huh J, Muramatsu H, O'Keefe C, Hsi E, Paquette RL, et al. 2009. Mutations of e 3 ubiquitin ligase cbl family members constitute a novel common pathogenic lesion in myeloid malignancies. J Clin Oncol 27: 6109-6116. doi:10.1200/ JCO.2009.23.7503

Malcovati L, Papaemmanuil E, Bowen DT, Boultwood J, Della Porta MG, Pascutto C, Travaglino E, Groves MJ, Godfrey AL, Ambaglio I, et al. 2011. Clinical significance of SF3B1 mutations in myelodysplastic syndromes and myelodysplastic/myeloproliferative neoplasms. Blood 118: 6239-6246. doi:10.1182/blood-2011-09-377275

McKenney AS, Lau AN, Somasundara AVH, Spitzer B, Intlekofer AM, Ahn J, Shank K, Rapaport FT, Patel MA, Papalexi E, et al. 2018a. JAK2/IDH-mutant-driven myeloproliferative neoplasm is sensitive to combined targeted inhibition. J Clin Invest 128: 789-804. doi:10.1172/ JCI94516

McKenney AS, Lau AN, Somasundara AVH, Spitzer B, Intlekofer AM, Ahn J, Shank K, Rapaport FT, Patel MA, Papalexi E, et al. 2018b. JAK2/IDH-mutant-driven myeloproliferative neoplasm is sensitive to combined targeted inhibition. JClin Invest 128: 4743. doi:10.1172/JCI124920

McNamara CJ, Panzarella T, Kennedy JA, Arruda A, Claudio JO, Daher-Reyes G, Ho J, Siddiq N, Devlin R, Tsui H, et al. 2018. The mutational landscape of accelerated-and blast-phase myeloproliferative neoplasms impacts patient outcomes. Blood Adv 2: 2658-2671. doi:10.1182/bloodad vances.2018021469

Mead AJ, Mullally A. 2017. Myeloproliferative neoplasm stem cells. Blood 129: 1607-1616. doi:10.1182/blood2016-10-696005

Milosevic Feenstra JD, Nivarthi H, Gisslinger H, Leroy E, Rumi E, Chachoua I, Bagienski K, Kubesova B, Pietra D, Gisslinger B, et al. 2016. Whole-exome sequencing identifies novel MPL and JAK2 mutations in triple-negative myeloproliferative neoplasms. Blood 127: 325-332. doi:10.1182/blood-2015-07-661835

Minor EA, Court BL, Young JI, Wang G. 2013. Ascorbate induces ten-eleven translocation (Tet) methylcytosine dioxygenase-mediated generation of 5-hydroxymethylcytosine. J Biol Chem 288: 13669-13674. doi:10.1074/jbc .C113.464800

Mohapatra B, Ahmad G, Nadeau S, Zutshi N, An W, Scheffe S, Dong L, Feng D, Goetz B, Arya P, et al. 2013. Protein tyrosine kinase regulation by ubiquitination: Critical roles of Cbl-family ubiquitin ligases. Biochim Biophys Acta 1833: 122-139. doi:10.1016/j.bbamcr.2012.10.010

Mullally A, Bruedigam C, Poveromo L, Heidel FH, Purdon A, Vu T, Austin R, Heckl D, Breyfogle LJ, Kuhn CP, et al. 2013. Depletion of Jak2V617F myeloproliferative neoplasm-propagating stem cells by interferon- $\alpha$ in a murine model of polycythemia vera. Blood 121: 3692-3702. doi:10.1182/blood-2012-05-432989 
A.E. Marneth and A. Mullally

Muramatsu H, Makishima H, Jankowska AM, Cazzolli H, O'Keefe C, Yoshida N, Xu Y, Nishio N, Hama A, Yagasaki $\mathrm{H}$, et al. 2010. Mutations of an E3 ubiquitin ligase cCbl but not TET2 mutations are pathogenic in juvenile myelomonocytic leukemia. Blood 115: 1969-1975. doi:10.1182/blood-2009-06-226340

Nagase R, Inoue D, Pastore A, Fujino T, Hou HA, Yamasaki N, Goyama S, Saika M, Kanai A, Sera Y, et al. 2018. Expression of mutant Asxll perturbs hematopoiesis and promotes susceptibility to leukemic transformation. $J$ Exp Med 215: 1729-1747. doi:10.1084/jem.20171151

Nangalia J, Massie CE, Baxter EJ, Nice FL, Gundem G, Wedge DC, Avezov E, Li J, Kollmann K, Kent DG, et al. 2013. Somatic CALR mutations in myeloproliferative neoplasms with nonmutated JAK2. N Engl J Med 369: 2391-2405. doi:10.1056/NEJMoa1312542

Nangalia J, Nice FL, Wedge DC, Godfrey AL, Grinfeld J, Thakker C, Massie CE, Baxter J, Sewell D, Silber Y, et al. 2015. DNMT3A mutations occur early or late in patients with myeloproliferative neoplasms and mutation order influences phenotype. Haematologica 100: e438-e442. doi:10.3324/haematol.2015.129510

Newberry KJ, Patel K, Masarova L, Luthra R, Manshouri T, Jabbour E, Bose P, Daver N, Cortes J, Kantarjian H, et al. 2017. Clonal evolution and outcomes in myelofibrosis after ruxolitinib discontinuation. Blood 130: 1125-1131. doi:10.1182/blood-2017-05-783225

Nguyen HD, Leong WY, Li W, Reddy PNG, Sullivan JD, Walter MJ, Zou L, Graubert TA. 2018. Spliceosome mutations induce R loop-associated sensitivity to ATR inhibition in myelodysplastic syndromes. Cancer Res 78: 5363-5374. doi:10.1158/0008-5472.CAN-17-3970

Niihori T, Aoki Y, Ohashi H, Kurosawa K, Kondoh T, Ishikiriyama S, Kawame H, Kamasaki H, Yamanaka T, Takada F, et al. 2005. Functional analysis of PTPN11/SHP-2 mutants identified in Noonan syndrome and childhood leukemia. J Hum Genet 50: 192-202. doi:10.1007/s10038005-0239-7

Ortmann CA, Kent DG, Nangalia J, Silber Y, Wedge DC, Grinfeld J, Baxter EJ, Massie CE, Papaemmanuil E, Menon S, et al. 2015. Effect of mutation order on myeloproliferative neoplasms. $N$ Engl J Med 372: 601-612. doi:10 .1056/NEJMoa1412098

Palangat M, Anastsakis D, Liang F, Lindblad K, Bradley R, Hourigan C, Hafner M, Larson D. 2018. The splicing factor U2AF1 contributes to cancer progression through a non-canonical role in translation regulation. Genes Dev 33: 482-497. doi:10.1101/gad.319590.118

Papaemmanuil E, Cazzola M, Boultwood J, Malcovati L, Vyas P, Bowen D, Pellagatti A, Wainscoat JS, Hellstrom-Lindberg E, Gambacorti-Passerini C, et al. 2011. Somatic SF3B1 mutation in myelodysplasia with ring sideroblasts. N Eng J Med 365: 1384-1395. doi:10.1056/ NEJMoa1103283

Pardanani A, Lasho TL, Finke CM, Mai M, McClure RF, Tefferi A. 2010. IDH1 and IDH2 mutation analysis in chronic- and blast-phase myeloproliferative neoplasms. Leukemia 24: 1146-1151. doi:10.1038/leu.2010.77

Park SM, Ou J, Chamberlain L, Simone TM, Yang H, Virbasius CM, Ali AM, Zhu LJ, Mukherjee S, Raza A, et al. 2016. U2AF35(S34F) promotes transformation by direct- ing aberrant ATG7 pre-mRNA $3^{\prime}$ end formation. Mol Cell 62: 479-490. doi:10.1016/j.molcel.2016.04.011

Peeken JC, Jutzi JS, Wehrle J, Koellerer C, Staehle HF, Becker H, Schoenwandt E, Seeger TS, Schanne DH, Gothwal M, et al. 2018. Epigenetic regulation of NFE2 overexpression in myeloproliferative neoplasms. Blood 131: 2065-2073. doi:10.1182/blood-2017-10-810622

Pikman Y, Lee BH, Mercher T, McDowell E, Ebert BL, Gozo M, Cuker A, Wernig G, Moore S, Galinsky I, et al. 2006. MPLW515L is a novel somatic activating mutation in myelofibrosis with myeloid metaplasia. PLoS Med 3: e270. doi:10.1371/journal.pmed.0030270

Przychodzen B, Jerez A, Guinta K, Sekeres MA, Padgett R, Maciejewski JP, Makishima H. 2013. Patterns of missplicing due to somatic U2AF1 mutations in myeloid neoplasms. Blood 122: 999-1006. doi:10.1182/blood-201301-480970

Rampal R, Ahn J, Abdel-Wahab O, Nahas M, Wang K, Lipson D, Otto GA, Yelensky R, Hricik T, McKenney AS, et al. 2014. Genomic and functional analysis of leukemic transformation of myeloproliferative neoplasms. Proc Natl Acad Sci 111: E5401-E5410. doi:10.1073/pnas .1407792111

Ran D, Shia WJ, Lo MC, Fan JB, Knorr DA, Ferrell PI, Ye Z, Yan M, Cheng L, Kaufman DS, et al. 2013. RUNX1a enhances hematopoietic lineage commitment from human embryonic stem cells and inducible pluripotent stem cells. Blood 121: 2882-2890. doi:10.1182/blood2012-08-451641

Rao N, Butcher CM, Lewis ID, Ross DM, Melo JV, Scott HS, Bardy PG, D'Andrea RJ. 2012. Clonal and lineage analysis of somatic DNMT3A and JAK2 mutations in a chronic phase polycythemia vera patient. Br J Haematol 156: 268270. doi:10.1111/j.1365-2141.2011.08837.x

Rasmussen KD, Jia G, Johansen JV, Pedersen MT, Rapin N, Bagger FO, Porse BT, Bernard OA, Christensen J, Helin K. 2015. Loss of TET2 in hematopoietic cells leads to DNA hypermethylation of active enhancers and induction of leukemogenesis. Genes Dev 29: 910-922. doi:10.1101/gad .260174 .115

Rotter V. 1983. p53, a transformation-related cellular-encoded protein, can be used as a biochemical marker for the detection of primary mouse tumor cells. Proc Natl Acad Sci 80: 2613-2617. doi:10.1073/pnas.80.9.2613

Ruark E, Snape K, Humburg P, Loveday C, Bajrami I, Brough R, Rodrigues DN, Renwick A, Seal S, Ramsay E, et al. 2013. Mosaic PPM1D mutations are associated with predisposition to breast and ovarian cancer. Nature 493: 406-410. doi:10.1038/nature11725

Saika M, Inoue D, Nagase R, Sato N, Tsuchiya A, Yabushita T, Kitamura T, Goyama S. 2018. ASXL1 and SETBP1 mutations promote leukaemogenesis by repressing TGF $\beta$ pathway genes through histone deacetylation. Sci Rep 8: 15873. doi:10.1038/s41598-018-33881-2

Sakurai H, Harada Y, Ogata Y, Kagiyama Y, Shingai N, Doki N, Ohashi K, Kitamura T, Komatsu N, Harada H. 2017. Overexpression of RUNX1 short isoform has an important role in the development of myelodysplastic/myeloproliferative neoplasms. Blood Adv 1: 1382-1386. doi:10 $.1182 /$ bloodadvances.2016002725

Sanada M, Suzuki T, Shih LY, Otsu M, Kato M, Yamazaki S, Tamura A, Honda H, Sakata-Yanagimoto M, Kumano K, 
et al. 2009. Gain-of-function of mutated C-CBL tumour suppressor in myeloid neoplasms. Nature 460: 904-908. doi:10.1038/nature08240

Sasaki M, Knobbe CB, Munger JC, Lind EF, Brenner D, Brustle A, Harris IS, Holmes R, Wakeham A, Haight J, et al. 2012. IDH1(R132H) mutation increases murine haematopoietic progenitors and alters epigenetics. Nature 488: 656-659. doi:10.1038/nature11323

Scheuermann JC, de Ayala Alonso AG, Oktaba K, Ly-Hartig N, McGinty RK, Fraterman S, Wilm M, Muir TW, Müller J. 2010. Histone H2A deubiquitinase activity of the Polycomb repressive complex PR-DUB. Nature 465: 243-247. doi:10.1038/nature08966

Schubbert S, Shannon K, Bollag G. 2007. Hyperactive Ras in developmental disorders and cancer. Nat Rev Cancer 7: 295-308. doi:10.1038/nrc2109

Scott LM, Tong W, Levine RL, Scott MA, Beer PA, Stratton MR, Futreal PA, Erber WN, McMullin MF, Harrison CN et al. 2007. JAK2 exon 12 mutations in polycythemia vera and idiopathic erythrocytosis. N Engl J Med 356: 459468. doi:10.1056/NEJMoa065202

Seita J, Ema H, Ooehara J, Yamazaki S, Tadokoro Y, Yamasaki A, Eto K, Takaki S, Takatsu K, Nakauchi H. 2007. Lnk negatively regulates self-renewal of hematopoietic stem cells by modifying thrombopoietin-mediated signal transduction. Proc Natl Acad Sci 104: 2349-2354. doi:10 $.1073 /$ pnas.0606238104

Shen H, Zheng X, Luecke S, Green MR. 2010. The U2AF35related protein Urp contacts the $3^{\prime}$ splice site to promote U12-type intron splicing and the second step of U2-type intron splicing. Genes Dev 24: 2389-2394. doi:10.1101/ gad.1974810

Shi ZQ, Yu DH, Park M, Marshall M, Feng GS. 2000. Molecular mechanism for the Shp-2 tyrosine phosphatase function in promoting growth factor stimulation of Erk activity. Mol Cell Biol 20: 1526-1536. doi:10.1128/MCB .20.5.1526-1536.2000

Shimizu T, Kubovcakova L, Nienhold R, Zmajkovic J, Meyer SC, Hao-Shen H, Geier F, Dirnhofer S, Guglielmelli P, Vannucchi AM, et al. 2016. Loss of Ezh2 synergizes with JAK2-V617F in initiating myeloproliferative neoplasms and promoting myelofibrosis. J Exp Med 213: 1479-1496. doi:10.1084/jem.20151136

Simon C, Dondi E, Chaix A, de Sepulveda P, Kubiseski TJ, Varin-Blank N, Velazquez L. 2008. Lnk adaptor protein down-regulates specific Kit-induced signaling pathways in primary mast cells. Blood 112: 4039-4047. doi:10 1182/blood-2008-05-154849

Stegelmann F, Bullinger L, Schlenk RF, Paschka P, Griesshammer M, Blersch C, Kuhn S, Schauer S, Döhner H, Döhner K. 2011. DNMT3A mutations in myeloproliferative neoplasms. Leukemia 25: 1217-1219. doi:10.1038/ leu.2011.77

Tahiliani M, Koh KP, Shen Y, Pastor WA, Bandukwala H, Brudno Y, Agarwal S, Iyer LM, Liu DR, Aravind L, et al. 2009. Conversion of 5-methylcytosine to 5-hydroxymethylcytosine in mammalian DNA by MLL partner TET1. Science 324: 930-935. doi:10.1126/science.1170116

Takaki S, Sauer K, Iritani BM, Chien S, Ebihara Y, Tsuji K, Takatsu K, Perlmutter RM. 2000. Control of B cell production by the adaptor protein lnk. Definition of a con- served family of signal-modulating proteins. Immunity 13: 599-609. doi:10.1016/S1074-7613(00)00060-1

Takaki S, Morita H, Tezuka Y, Takatsu K. 2002. Enhanced hematopoiesis by hematopoietic progenitor cells lacking intracellular adaptor protein, Lnk. J Exp Med 195: 151160. doi:10.1084/jem.20011170

Takizawa H, Eto K, Yoshikawa A, Nakauchi H, Takatsu K, Takaki S. 2008. Growth and maturation of megakaryocytes is regulated by Lnk/Sh2b3 adaptor protein through crosstalk between cytokine- and integrin-mediated signals. Exp Hematol 36: 897-906. doi:10.1016/j.exphem 2008.02.004

Tartaglia M, Niemeyer CM, Fragale A, Song X, Buechner J, Jung A, Hählen K, Hasle H, Licht JD, Gelb BD. 2003. Somatic mutations in PTPN11 in juvenile myelomonocytic leukemia, myelodysplastic syndromes and acute myeloid leukemia. Nat Genet 34: 148-150. doi:10.1038/ ng1156

Tartaglia M, Martinelli S, Stella L, Bocchinfuso G, Flex E, Cordeddu V, Zampino G, Burgt I, Palleschi A, Petrucci TC, et al. 2006. Diversity and functional consequences of germline and somatic PTPN11 mutations in human disease. Am J Hum Genet 78: 279-290. doi:10.1086/499925

Tefferi A, Lasho TL, Abdel-Wahab O, Guglielmelli P, Patel J, Caramazza D, Pieri L, Finke CM, Kilpivaara O, Wadleigh $\mathrm{M}$, et al. 2010. IDH1 and IDH2 mutation studies in 1473 patients with chronic-, fibrotic- or blast-phase essential thrombocythemia, polycythemia vera or myelofibrosis. Leukemia 24: 1302-1309. doi:10.1038/leu.2010.113

Tefferi A, Guglielmelli P, Lasho TL, Rotunno G, Finke C, Mannarelli C, Belachew AA, Pancrazzi A, Wassie EA, Ketterling RP, et al. 2014. CALR and ASXL1 mutationsbased molecular prognostication in primary myelofibrosis: An international study of 570 patients. Leukemia 28: 1494-1500. doi:10.1038/leu.2014.57

Tefferi A, Lasho TL, Finke CM, Elala Y, Hanson CA, Ketterling RP, Gangat N, Pardanani A. 2016a. Targeted deep sequencing in primary myelofibrosis. Blood Adv 1: 105111. doi:10.1182/bloodadvances.2016000208

Tefferi A, Lasho TL, Guglielmelli P, Finke CM, Rotunno G, Elala Y, Pacilli A, Hanson CA, Pancrazzi A, Ketterling RP, et al. 2016b. Targeted deep sequencing in polycythemia vera and essential thrombocythemia. Blood Adv 1:21-30. doi:10.1182/bloodadvances.2016000216

Tefferi A, Finke CM, Lasho TL, Hanson CA, Ketterling RP, Gangat N, Pardanani A. 2018a. U2AF1 mutation types in primary myelofibrosis: Phenotypic and prognostic distinctions. Leukemia 32: 2274-2278. doi:10.1038/s41375018-0078-0

Tefferi A, Lasho TL, Finke C, Gangat N, Hanson CA, Ketterling RP, Pardanani A. 2018b. Prognostic significance of ASXL1 mutation types and allele burden in myelofibrosis. Leukemia 32: 837-839. doi:10.1038/leu.2017.318

Tefferi A, Lasho TL, Hanson CA, Ketterling RP, Gangat N, Pardanani A. 2018c. Screening for ASXL1 and SRSF2 mutations is imperative for treatment decision-making in otherwise low or intermediate-1 risk patients with myelofibrosis. Br J Haematol 183: 678-681. doi:10.1111/bjh .15010

Tefferi A, Nicolosi M, Mudireddy M, Szuber N, Finke CM, Lasho TL, Hanson CA, Ketterling RP, Pardanani A, Gangat N, et al. 2018d. Driver mutations and prognosis 
A.E. Marneth and A. Mullally

in primary myelofibrosis: Mayo-Careggi MPN alliance study of 1,095 patients. Am J Hematol 93: 348-355. doi:10.1002/ajh.24978

Thien CB, Langdon WY. 2005. Negative regulation of PTK signalling by $\mathrm{Cbl}$ proteins. Growth Factors 23: 161-167. doi:10.1080/08977190500153763

Tong W, Zhang J, Lodish HF. 2005. Lnk inhibits erythropoiesis and Epo-dependent JAK2 activation and downstream signaling pathways. Blood 105: 4604-4612. doi:10.1182/ blood-2004-10-4093

Tsuzuki S, Seto M. 2012. Expansion of functionally defined mouse hematopoietic stem and progenitor cells by a short isoform of RUNX1/AML1. Blood 119: 727-735. doi:10 .1182/blood-2011-06-362277

Uni M, Masamoto Y, Sato T, Kamikubo Y, Arai S, Hara E, Kurokawa M. 2019. Modeling ASXL1 mutation revealed impaired hematopoiesis caused by derepression of p16Ink4a through aberrant PRC1-mediated histone modification. Leukemia 33: 191-204. doi:10.1038/ s41375-018-0198-6

Vannucchi AM, Lasho TL, Guglielmelli P, Biamonte F, Pardanani A, Pereira A, Finke C, Score J, Gangat N, Mannarelli C, et al. 2013. Mutations and prognosis in primary myelofibrosis. Leukemia 27: 1861-1869. doi:10.1038/leu .2013 .119

Velazquez L, Cheng AM, Fleming HE, Furlonger C, Vesely S, Bernstein A, Paige CJ, Pawson T. 2002. Cytokine signaling and hematopoietic homeostasis are disrupted in Lnk-deficient mice. J Exp Med 195: 1599-1611. doi:10.1084/jem .20011883

Venton G, Courtier F, Charbonnier A, D'Incan E, Saillard C, Mohty B, Mozziconacci MJ, Birnbaum D, Murati A, Vey $\mathrm{N}$, et al. 2018. Impact of gene mutations on treatment response and prognosis of acute myeloid leukemia secondary to myeloproliferative neoplasms. Am J Hematol 93: 330-338. doi:10.1002/ajh.24973

Verma B, Akinyi MV, Norppa AJ, Frilander MJ. 2018. Minor spliceosome and disease. Semin Cell Dev Biol 79: $103-$ 112. doi:10.1016/j.semcdb.2017.09.036

Wang M, He N, Tian T, Liu L, Yu S, Ma D. 2014. Mutation analysis of JAK2V617F, FLT3-ITD, NPM1, and DNMT3A in Chinese patients with myeloproliferative neoplasms. Biomed Res Int 2014: 485645. doi:10.1155/ $2014 / 485645$

Watanabe-Okochi N, Kitaura J, Ono R, Harada H, Harada Y, Komeno Y, Nakajima H, Nosaka T, Inaba T, Kitamura T. 2008. AML1 mutations induced MDS and MDS/AML in a mouse BMT model. Blood 111: 4297-4308. doi:10 .1182/blood-2007-01-068346

Webb CJ, Wise JA. 2004. The splicing factor U2AF small subunit is functionally conserved between fission yeast and humans. Mol Cell Biol 24: 4229-4240. doi:10.1128/ MCB.24.10.4229-4240.2004

Wolach O, Sellar RS, Martinod K, Cherpokova D, McConkey M, Chappell RJ, Silver AJ, Adams D, Castellano CA,
Schneider RK, et al. 2018. Increased neutrophil extracellular trap formation promotes thrombosis in myeloproliferative neoplasms. Sci Transl Med 10: eaan8292. doi:10 $.1126 /$ scitranslmed.aan8292

Xiao R, Sun Y, Ding JH, Lin S, Rose DW, Rosenfeld MG, Fu XD, Li X. 2007. Splicing regulator SC35 is essential for genomic stability and cell proliferation during mammalian organogenesis. Mol Cell Biol 27: 5393-5402. doi:10 .1128/MCB.00288-07

Xie M, Lu C, Wang J, McLellan MD, Johnson KJ, Wendl MC, McMichael JF, Schmidt HK, Yellapantula V, Miller CA, et al. 2014. Age-related mutations associated with clonal hematopoietic expansion and malignancies. Nat Med 20: 1472-1478. doi:10.1038/nm.3733

Xu W, Yang H, Liu Y, Yang Y, Wang P, Kim SH, Ito S, Yang C, Wang P, Xiao MT, et al. 2011. Oncometabolite 2-hydroxyglutarate is a competitive inhibitor of $\alpha$-ketoglutarate-dependent dioxygenases. Cancer Cell 19: 17-30. doi:10.1016/j.ccr.2010.12.014

Yamashita Y, Yuan J, Suetake I, Suzuki H, Ishikawa Y, Choi YL, Ueno T, Soda M, Hamada T, Haruta H, et al. 2010. Array-based genomic resequencing of human leukemia. Oncogene 29: 3723-3731. doi:10.1038/onc.2010.117

Yang Y, Akada H, Nath D, Hutchison RE, Mohi G. 2016. Loss of Ezh2 cooperates with Jak2V617F in the development of myelofibrosis in a mouse model of myeloproliferative neoplasm. Blood 127: 3410-3423. doi:10.1182/ blood-2015-11-679431

Yang H, Kurtenbach S, Guo Y, Lohse I, Durante MA, Li J, Li Z, Al-Ali H, Li L, Chen Z, et al. 2018. Gain of function of ASXL1 truncating protein in the pathogenesis of myeloid malignancies. Blood 131: 328-341. doi:10.1182/blood2017-06-789669

Yonal-Hindilerden I, Daglar-Aday A, Hindilerden F, Akadam-Teker B, Yilmaz C, Nalcaci M, Yavuz AS, Sargin D. 2016. The clinical significance of IDH mutations in essential thrombocythemia and primary myelofibrosis. $J$ Clin Med Res 8: 29-39. doi:10.14740/jocmr2405w

Yoshida K, Sanada M, Shiraishi Y, Nowak D, Nagata Y, Yamamoto R, Sato Y, Sato-Otsubo A, Kon A, Nagasaki M, et al. 2011. Frequent pathway mutations of splicing machinery in myelodysplasia. Nature 478: 64-69. doi:10 $.1038 /$ nature 10496

Zhang SJ, Rampal R, Manshouri T, Patel J, Mensah N, Kayserian A, Hricik T, Heguy A, Hedvat C, Gonen M, et al. 2012. Genetic analysis of patients with leukemic transformation of myeloproliferative neoplasms shows recurrent SRSF2 mutations that are associated with adverse outcome. Blood 119: 4480-4485. doi:10.1182/blood-201111-390252

Zhang L, Chen LH, Wan H, Yang R, Wang Z, Feng J, Yang S, Jones S, Wang S, Zhou W, et al. 2014. Exome sequencing identifies somatic gain-of-function PPM1D mutations in brainstem gliomas. Nat Genet 46: 726-730. doi:10.1038/ ng. 2995 


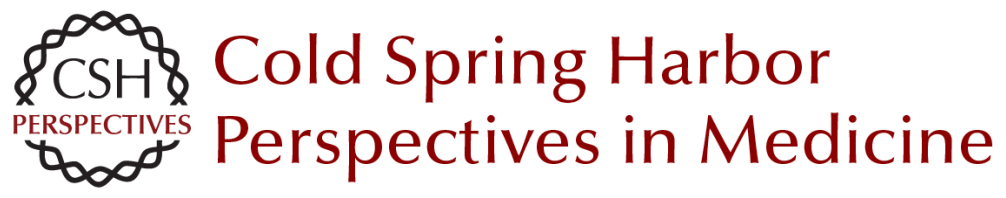

\section{The Molecular Genetics of Myeloproliferative Neoplasms}

Anna E. Marneth and Ann Mullally

Cold Spring Harb Perspect Med 2020; doi: 10.1101/cshperspect.a034876 originally published online September 23, 2019

\section{Subject Collection Leukemia and Lymphoma: Molecular and Therapeutic Insights}

Oncogenic Mechanisms and Therapeutic Targeting of Metabolism in Leukemia and Lymphoma

Maximilian Stahl, Zachary D. Epstein-Peterson and Andrew M. Intlekofer

Non-Hodgkin Lymphomas: Malignancies Arising from Mature B Cells Jennifer Shingleton, Jie Wang, Carolyn Baloh, et al.

MAP-Kinase-Driven Hematopoietic Neoplasms: A Decade of Progress in the Molecular Age Rikhia Chakraborty, Omar Abdel-Wahab and Benjamin H. Durham

Mouse Models in the Study of Mature B-Cell Malignancies Laura Pasqualucci and Ulf Klein

Mouse Models of Myeloid Malignancies Faisal Basheer and George Vassiliou

Epigenetic Mechanisms in Leukemias and Lymphomas

Cihangir Duy, Wendy Béguelin and Ari Melnick

The Biology of B-Progenitor Acute Lymphoblastic Leukemia

Kathryn G. Roberts and Charles G. Mullighan

RNA Regulators in Leukemia and Lymphoma Camila Prieto and Michael G. Kharas
Biological and Translational Considerations regarding the Recent Therapeutic Successes and Upcoming Challenges for Multiple Myeloma Constantine S. Mitsiades

Biology and Molecular Pathogenesis of Mature T-Cell Lymphomas José R. Cortés and Teresa Palomero

The Role of Somatic Mutations in Acute Myeloid Leukemia Pathogenesis Ashwin Kishtagari and Ross L. Levine

Chronic Lymphocytic Leukemia Nicholas Chiorazzi, Shih-Shih Chen and Kanti R. Rai

Normal Hematopoiesis Is a Balancing Act of

Self-Renewal and Regeneration Oakley C. Olson, Yoon-A Kang and Emmanuelle Passegué

Impact of Genetics on Mature Lymphoid

Leukemias and Lymphomas

Nathanael G. Bailey and Kojo S.J. Elenitoba-Johnson

Epidemiology and Etiology of Leukemia and

Lymphoma Jordan A. Baeker Bispo, Paulo S. Pinheiro and Erin K. Kobetz

Clonal Hematopoiesis and Premalignant Diseases Justin Kaner, Pinkal Desai, Nuria Mencia-Trinchant, et al.

For additional articles in this collection, see http://perspectivesinmedicine.cshlp.org/cgi/collection/ 